\title{
Demirci Camilerindeki Ahşap Tavan Göbekleri
}

\begin{abstract}
Öz: Demirci Manisa'nın bir ilçesi olup, il merkezine $160 \mathrm{~km}$. mesafede bir yerleşim yeridir. Ahşap tavanlı cami yapma geleneğinin kökeni, Orta Asya Karahanlılar devrine kadar gitmektedir. Bu gelenek Anadolu'da da devam ettirilmiştir. Büyük Selçuklu, Gazneli, Anadolu Selçuklu, Beylikler ve Osmanlı devirlerinde bu teknikte Anadolu'da birçok cami inşa edilmiştir. 12. yüzyıldan 20. yüzyıl başlarına kadar Ankara, Konya, Niğde, Afyon ve Kastamonu çevreleri başta olmak üzere Anadolu'nun birçok bölgesinde ahşap tavanlı ibadet yapıları görmek mümkündür. Türkiye'nin birçok yöresinde olduğu gibi Demirci ilçesinde de tavanlı câmiler inşa edilmiştir. Bunlar daha çok 19. yüzyıla ait örneklerdir. Bu çalışmanın konusu olan Demirci'deki ahşap tavan göbekli 13 adet cami, 18-20. yüzyıl mimarisi ve bezemesi hakkında değerli bilgiler sunmaktadır. Daha önce çalışılmamış olan bu eserler; plan, malzeme ve bezeme özellikleri bağlamında incelenmiştir. İncelenen eserlerin, Türk sanatındaki yeri ve önemi ortaya konulmaya çalışılmıştır. Ayrıca günümüzde kaderine terkedilmiş durumda olan eserlerin korunması yönünde adımlar atılacaktır.
\end{abstract}

Anahtar Kelimeler: Manisa, Demirci, Cami, Ahşap, Ahşap Tavan.

\section{Halil İbrahim ERYILMAZ}

\section{Wooden Ceiling Centre-Pieces in Demirci Mosques}

Abstract: Demirci is a district of Manisa, it is a settlement $160 \mathrm{~km}$ from the city center. The origin of the tradition of making wooden ceilings dates back to the Karahanids. This tradition continued also in Anatolia. During the Great Seljukian, Ghaznavid, the Anatolian Seljukian, Principalities (Beyliqs) and Ottoman periods many mosques were built in this technique in Anatolia. From 12th through 20th century, it is possible to see religious constructions with wooden ceilings in a great many parts of Anatolia, particularly in and around Ankara, Konya, Niğde, Afyon and Kastamonu. As in many provinces of Turkey, mosques with wooden ceilings were constructed in Demirci as well, mostly from 19th century. The thirteen mosques with wooden ceilings centre-pieces in Demirci, which is the subject of this study, provide valuable information about the architecture and ornaments of the 18th-20th century. The buildings that have not been studied before have examined in the context of their plan, material and the ornament features. It has been tried to reveal the importance in Turkish art of the buildings that examined. Also, it will be taken a step to protect of these buildings that have survived in a dilapidated condition at the present day.

Keywords: Manisa, Demirci, Mosque, Wooden, Wooden Ceiling. 


\section{Giriş}

Türk İslâm sanatının estetik zenginliğine katkıda bulunan önemli bir sanat dalı da ahşap işçiliğidir. Ahşap, doğal yapı malzemeleri içinde elde edilmesi, taşınması ve uygulanması en kolay olan bir yapı unsurudur. Ayrıca organik nem kapıcı ve anizotropik bir malzemedir. Isıya karşı neredeyse genleşmemesi, ses emilimi için ideal olması, statik elektriği içermemesi, hafif, bol çeşitli ve dekoratif oluşu gibi özellikleri, ahşabı bir inşaat malzemesi olarak kullanmak için oldukça uygun yapmaktadır. ${ }^{1}$ Bu kolaylığının ötesinde ahşap, sıcak dokulu bir malzemedir. Sıcağı depolar ve insan duyguları üzerinde olumlu bir etki yaratır. Ayrıca ahşap, dünyanın faniliği düşüncesinin simgesi haline gelmiştir. ${ }^{2}$ Bütün bunlardan dolayı İslâm sanatının bütün dönemlerinde sevilerek kullanılan bir malzeme olmuştur. Bazen yapının bütünü, bazen de çatı ve tavanlar ile tavanı taşıyan destekler ahşap malzeme ile inşa edilmiştir. Ahşap sanatında ağaçlar ceviz, ıhlamur, şimşir, meşe, elma, sedir ve armut gibi yerli ağaçlarla; abanoz ve gül gibi dışarıdan getirilen tropikal ağaçlar tercih edilmiştir. İslâm dininin plastik şekilde tasvirleri uygun görmemesi sebebiyle oymacılık bağımsız bir sanat olarak gelişmemiş, her zaman mimariye bağlı bir süsleme unsuru olmuştur. ${ }^{3}$ Ahşap malzemeyi, taşınabilir ve taşınmaz özellikli ağaç işleri olarak iki başlıkta ele alınabilir. Taşınmaz özellikli olanlar kendi arasında mimariyi oluşturan ya da mimariyi tamamlayan elemanlar olarak ikiye ayrılabilir. Sütun, ayak, tavan, çatı, duvar, taban vb. elemanlar mimariyi oluşturan ögelerdir. Kapı ve pencere kanatları, minber, kürsü ve mihrap vb. elemanlar mimariyi tamamlayıcı unsurlardır. Rahle, Kur'an ve cüz mahfazası, sandık, sehpa vb. ise taşınabilir ahşap malzemelere örnektir. ${ }^{4}$

İslâm mimarisinde, kerpiç duvarlarla çevrili avlu içindeki gölgeliğin hurma ağacı gövdelerinden yapılmış olmasından hareketle, Hazret-i Muhammed'in (sav) Medine'deki mescidi ilk ağaç direkli cami kabul edilmektedir. Bu uygulama Fustat'ta Amr ibnü'l-As Camii'nde olduğu gibi yedinci yüzyılın ilk yarısında inşa edilen bazı camilerde de uygulanmıştır. Fustat'ta Amr ibnü'l-As tarafından inşa ettirilen camiye hurma ağacı gövdelerinden kirişler yapılmış, tavan yine hurma ağacından dolu'nun Ahşap Evleri içinde, (Ankara: Kültür Bakanlığı Yayınları, 2001), 1-5.

2 Haşim Karpuz, “Erzurum ve Konya Evlerinde Ahşap Malzeme Kullanımı”, Ahşap Kültürü AnadoIu’nun Ahşap Evleri, ed. Aysun Özköse, (Ankara: Kültür Bakanlığı Yayınları, 2001), 114; Doğan Kuban, Kaybolan Kent Hayalleri Ahşap Saraylar, (İstanbul: Yapı Endüstri Merkezi Yayınları, 2001), 9-104.

3 Erdem Yücel, "Ahşap", Diyanet islâm Ansiklopedisi, 2, (İstanbul: Diyanet Vakfı Yayınları, 1989): 182; Erdem Yücel, "Selçuklu Ağaç Iş̧̧iliği", Sanat Dünyamız, 4 (1975): 3.

4 H. Örcün Barışta, Osmanlı Imparatorluğu Dönemi Istanbul Cami ve Türbelerinden Ağaç İşleri, (Ankara: Atatürk Kültür Merkezi Yayınları, 2009), 2. 
yapılan direklere oturtulmuştur. Fakat daha sonra bu cami büyütülmüş, ağaç direkler kaldırılarak yerlerine mermer sütunlar konulmuştur. ${ }^{5}$ Camiü'l-Kebir'in tavanı zamanında ahşaptan yapılmış olup oyma tekniğiyle ve parlak renklerle süslenmiştir. Abbasi mimarisinin önemli eseri Samarra Camiü'l-Kebir'in mihrabının da süslü ahşap plakalarla kaplı olduğu nakledilmektedir. Ayrıca Aksa Camii ile İbn Tulun Camii'nin duvarları da zaman zaman büyük ahşap panolarla kaplanmıştır. ${ }^{6}$

Orta Asya karakterine bürünmüş olan ahşap sütunlu cami tipi Orta Asya'dan göçen Türkler tarafından Anadolu'ya getirilmiş ve ahşap sütunlu cami tipi Anadolu'da yeni gelişme alanları bulmuştur. ${ }^{7}$ Bunun en güzel ve en zengin örneklerini Anadolu Selçuklu sanatında görmek mümkündür. ${ }^{8}$ Ankara, Alâeddin Camii (1197) ${ }^{9}$, Afyon Ulu Camii (1273), Sivrihisar Ulu Camii (1274), Ankara Arslanhane (1289-90), Beyşehir Eşrefoğlu Camii (1298-99) ve Ayaş Ulu Camii (14./15. yüzyıl) iç mimaride ahşap malzemenin kullanıldığı, Selçuklu devrinin en fazla ün yapan örnekleridir. Bugün orijinal şeklini yitiren Erzurum Ulu Camii (1174-1189) ve Konya Sâhip Ata Camii (1258) gibi daha birçok Selçuklu camiinin, devrinde ahşap sütunlu olduğu tahmin edilmektedir. Ahşap sütunlu cami geleneğinin Orta Asya çadır sanatına dayandığı ve Türkistan'da bir grup ahşap direkli camilerle benzerlik gösterdiği kabul olunmaktadır. ${ }^{10}$

Selçukluların ahşap işçiliği, Beylikler devrinde de aynı üslûp, teknik ve işçilikle devam etmiştir. 14.-15. yüzyıl Beylikler devri cami ve mescitlerinde ahşap sütunlu ve tavanlı örnekler daha da artmıştır. Bu örnekler daha çok Kastamonu, Ankara gibi bölgelerde yoğunlaşmıştır. ${ }^{11} 13$. yüzyıl sonunda Ankara yöresinde son derce ileri bir ağaç işçiliği vardı. Buradaki çeşitli atölyelerden yetişen sanatkârlar Anadolu'nun birçok bölgesine dağılmışlardır. Anadolu Beyliklerinde Selçuklu geleneğini sürdüren Ankaralı sanatkârların imzalarına rastlanışı, burasının önemli bir ağaç işçiliği merkezi olduğunu göstermektedir. Selçuklu (Arslanhane Camii, Ahi Elvan Camii gibi.) ve Beylikler devri ağaç işçiliğinin en güzel örnekleri Ankara camilerinde bir araya toplanmıştır. ${ }^{12}$ Ankara Hacı İvaz Camii, Poyracı,

Aptullah Kuran, Anadolu'da Ahşap Sütunlu Selçuklu Mimarisi Malazgirt Armağanı, (Ankara:Türk Tarih Kurumu Yayınları, 1972), 180. Oleg Grabar, İslâm Sanatının Oluşumu, çev. Nuran Yavuz, (İstanbul: Kanat Yayınları, 2010), 113.

7 Kuran, Anadolu'da Ahşap Sütunlu Selçuklu Mimarisi, 181.

8 Ali Murat Aktemur, "Türk Ahşap İşçiliğii", Türkler, 6, (Ankara: Yeni Türkiye Yayınları, 2002): 99.

9 Demet Taşkan, "Ankara (Merkez) Cami ve Mescitlerindeki Ahşap Tavan Göbekleri”, Gazi Üniversitesi Sosyal Bilimler Dergisi, Özel Sayı, (Aralık 2016): 71-101.

10 Gönül Öney, Süsleme ve El Sanatları, (Ankara: Türkiye İş Bankası Yayınları, 1978), 141-142.

11 Öney, Süsleme ve EI Sanatları, 122-123.

12 Yücel, "Selçuklu Ağaç İşçiliği", 5. 
Örtmeli, Geneği, Sabûni, Eyyûbi Mescitleri; Kastamonu Kasaba Köyü Candaroğlu Mahmud Bey Köyü, Küre-i Hadid Köyü, İsmail Bey Camileri; Konya Meram, Niğde Şah Mescit, Beyşehir Köşk Köyü, Illisra Ulu ve Tekkeci Camileri, ahşap tavan kirişleri, konsolları, sütunları ve sütun başılıkları ile Türkistan geleneklerini Anadolu'da sürdüren, orijinal bir mimari oluşturan eserlere örnek gösterilebilir. ${ }^{13}$

Türk mimarlık tarihinde ahşap tavanlı ve ahşap direkli cami yapma geleneği Osmanlı döneminde de devam etmiştir. Çoğu ahşap olup, kerpiçle yapılan bu mescitler ahşap çatı ile örtülmüştür. Mimarîleri, ahşap konutların mimarîsine benzemektedirler. Plânları ve iç düzeniyle büyük camilerinkine benzemekle beraber, üslûp bakımından farklıdırlar. Bu mescitlerin iç süslemesi büyük camilerde olduğu gibi çinilerle yapılmamış; daha ucuza mal olan duvar resimleriyle ve ahşap boyamayla yapılmışır. ${ }^{14}$

Ahşap tavanlı cami yapma geleneği Karahanlı ve Gazneli dönemlerinde başlayıp Selçuklular, Beylikler ve Osmanlılarda da devam etmiştir. Anadolu'da 12. yüzyıldan itibaren ahşap tavanlı camileri görmek mümkündür. Aftundere Orhan Gazi Camii ve Orhan Gazi Çantı Câmii ahşap camilere örnek verilebilir. Ankara, Hacı Musa Camisi (1421), Ankara, Hacı Bayram Camisi (1428), Ankara, Zincirli Camisi (1685) ve Ankara, Hacı Ilyas Camisi (1701) ${ }^{15}$ de ahşap tavanlı camilerin güzel örneklerindendir. Hacı Bayram Camii, bir ev gibi sıcak halinden başka, sırlı tuğla ile yapılması, hareketli köşeleri, çatı dalgalanmaları, dolu ve boşluk oranları ile ayrıca bir güzelliğe sâhiptir. Bu câmiin özellikle harim tavan göbeği ile mahfilindeki tavan süslemesi son derece etkileyicidir. Fatih Dönemine ait Beyceğiz Mescidi, Yatağan Mescidi ${ }^{16}$ ve Manisa, Ali Bey Camii (1418) ${ }^{17}$ ahşap camilere örnek verilebilecek diğer eserlerdir. İstanbul, Takkeci İbrahim Ağa Camii (16. yüzyıl), Gelibolu Gazi Süleyman Paşa Camii (17. yüzyıl) ${ }^{18}$, Tokat, Genç Mehmet Paşa Camii (17.yüzyıl), Tokat, Mahmutpaşa Camii (17.yüzyıl), Tokat, Silahtar Ömer Paşa Camii (17.yüzyıl) ${ }^{19}$ Osmanlı Döneminde farklı bölgelerde, farklı zaman dilimlerinde inşa edilen ahşap tavanlı cami örneklerindendir.

\section{Öney, Süsleme ve El Sanatları, 123.}

Celal Esad Arseven, Türk Sanatı, (Yy: Cem Yayınevi, 1984), 89.

E. Hakkı Ayverdi ve İ. Aydın Yüksel, İlk 250 Senenin Osmanlı Mimarisi, (İstanbul: Baha Matbaası, 1976), 61; Taşkan, "Ahşap Tavan Göbekleri", 71-101.

Ayverdi ve Yüksel, Illk 250 Senenin Osmanlı Mimarisi, 189, 221.

Hakkı Acun, Manisa'da Türk Devri Yapıları, (Ankara:TTK Yayınları, 1999), 80.

Barışta, İstanbul Cami ve Türbelerinden Ağaç Iş̧leri, 428, 444.

Çiğdem Özay, Geometrik Kompozisyonların Tokat Yapılarındaki Ahşap Tavan Göbeklerine Yansıması; Mahmutpaşa Camii, Ulu Camii, Genç Mehmet Paşa Camii Örneği", Tokat Gaziosmanpaşa Üniversitesi Sosyal Bilimler Araştırmaları Dergisi, 15/1 (2020): 82. 
18. yüzyıldan itibaren başlayan ve 19. yüzyıla doğru etki alanını bütün Anadolu'ya yayan üslup değişikliklerinin etkileri ahşap camilerde de görülür. Bu camilerde ahşap işçilik minber, vaaz kürsüsü, tavan göbeği ve sütun başılıklarında yoğunlaşmaktadır. Batılı etkilerin bölgesel sanat anlayışlarıyla kaynaştııılarak bir arada kullanıldığı bu işçiliğin en güzel örneklerinden biri Ardahan Derviş Bey Camii'dir (1861). Bu eser, Doğu Anadolu'daki geç dönem Osmanlı ahşap iş̧̧iliğinin zengin örneklerini ve üslup değişiminin yöresel anlayışla kaynaşımını göstermektedir. ${ }^{20}$ Bir başka ahşap yapılı eser Emirgan Camii'dir. I. Abdülhamid'in eşi Hümaşah Sultan anısına 1781/82'de yapılan bu eser II. Mahmud tarafından 1838/39'da ahşap çatılı olarak yeniden inşa ettirilmiştir. Bu yapı sultan camileri içinde ahşap çatılı tek camidir. Diyarbakır'da 1869-75 yıllan arasında, Kurt lakapıı İsmail Paşa tarafından yaptırılan sekizgen planlı Kurt İsmail Paşa Camii de ahşap tavanlı ve ahşap çatılı bir camidir. Bu eser Osmanlı mimarisinde başka eşi olmayan bir geç dönem yapısıdır ${ }^{21}$. 19. yüzyıl eserlerinden Göynük, Gazi Süleyman Paşa Camii22, İstanbul, Çiçekçi Camii, Mehmet Tahir Efendi Camii, Vaniköy Camii Anadolu Hisarı'ndaki Fatih Camii, Defterdar Burnu İbrahim Paşa Camii ve Arpacılar Mescidi de süslemeli tavanlarılla dikkat çekicidir. ${ }^{23}$

Ayrıca Babakale Ulu Câmii (18. yüzyıl)24, Yozgat, Cevahir Ali Efendi Camii (1788), Soma Hızır Bey Camii (1792), Yozgat Başçavuşoglu Camii(18012) ${ }^{25}$, Denizli, Yazır Köyü Camii (1802)26, Niğde, Dörtayak Camii ${ }^{27}$, Gümüşhane, Örenşar Köyü Camii $(1835)^{28}$, Soma, Damgacı Camii (19. yüzyıl ilk yarısı) ${ }^{29}$, İzmir Namazgâh Kurşunlu Camii, Naturzade Camii (19. yüzyıl)³0, Amasya, Kızılkışlacık Köyü Camii (1865), Amas-

Aktemur, "Türk Ahşap İşçiliği", 103.

Doğan Kuban, Osmanlı Mimarisi, (istanbul: Yem Yayınları, 2007), 544,574.

Şenay Özgür Yıldız ve Aliye Özsüner, "Bolu Göynük'te Türk Devri Mimarisi”, Düzce Üniversitesi Sosyal Bilimler Enstitüsü Dergisi, 10/2 (2020): 343-345.

Barışta, İstanbul Cami ve Türbelerinden Ağaç İ̧̧leri, 266.

Zekiye Uysal, "18. Yüzyıldan Ahşap Direkli İki Cami", Turkish Studies - International Periodical For The Languages, Literature and History of Turkish or Turkic, 9/10 (Fall 2014): 1107-1123.

Rüçhan Arık, Batılılaşma Dönemi Türk Mimarisi Örneklerinden Anadolu'da Üç̧Ahşap Cami, (Ankara: Ankara Üniversitesi Basımevi: 1973), 10-28.

Rüçhan Arık, Anadolu Tasvir Sanatı, (Ankara: Kültür ve Turizm Bakanlığı Yayınları, 1988), 42-46. Halit Çal, Niğde Şehrindeki Ahşap Tavanlı Camiler ve Mescitler, (Ankara: Kültür Bakanlığı Yayınları, 2000), 77-86.

Haldun Özkan, "Gümüşhane'de Ahşap Tavanlı Camiler", Sanat Dergisi, 18 (2011): 63 - 80.

İnci Kuyulu, "Geç Dönem Anadolu Tasvir Sanatından Yeni Bir Örnek: Soma Damgacı Camii", Arkeoloji ve Sanat Tarihi Dergisi, 4 (1988): 67-78.

Harun Ürer, "izmir Kent Merkezinde Bulunan Cami ve Mescitlerden Örnekler", Tüba-Ked Türkiye Bilimler Akademisi Kültür Envanteri Dergisi, 16 (2017): 194-200. 
ya, Şıhlar Köyü Camisi ${ }^{31}$, Çaykara, Akköse Camii (19. yüzyıl) ${ }^{32}$, Çanakkale, Tıflı Camii $(1890)^{33}$, Bademli-Kılcızade Mehmet Ağa Cami (1898) ${ }^{34}$, Akseki Belenalan Köyü Camii (19. Yüzyıl), Antalya, Akseki Çimi Köyü Camii ${ }^{35}$, Antalya, Elmalı, Toklular Camii ${ }^{36}$, Pınarbaşı, Medhiye Köyü Camii (1902), Pınarbaşı, Hilmiye Köyü Camii (1904-06)"37, Burdur, Günalan (Lengüme) Köyü Camii (1892), Burdur, Gazi Camii (1916), Burdur Ulu Camii (1919) ${ }^{38}$ ile Gümüşhane, Köycük Eski Camii (1919-20) ${ }^{39}$ gibi eserler Osmanlı́nın son dönem sanat üslubunu açık bir şekilde sergilemektedirler.

Süsleme olarak, Anadolu Türk sanatında görülen geometrik kompozisyonların büyük bir kısmının ahşap malzeme üzerinde yer aldığı görülmektedir. ${ }^{40}$ Bunda geometrik motiflerin, ağaç üzerine oymacılıkta kullanılan maddenin doğal özelliğine çok iyi uyum sağlaması önemli bir etkendir. Geometrik motiflerin yanında bitkisel süsleme motiflerine de öncelik verilmiştir. Örneğin Selçuklu minberleri, Selçuklu taş tezyinatındaki rûmî, palmet ve lotus gibi bitkisel bezeme örneklerini içerir. ${ }^{41}$ Rûmî desenler arasına pek nadir olarak insan ve hayvan figürleri de yerleştirilmiştir. Selçuklu devri ağaç işlerinde bu örneklerin yanında tavus kuşu, Mühr-i Süleyman, yazı ve selvi gibi motiflere de zaman zaman rastlanmaktadır. ${ }^{42}$

Ahşap sanatı en yüksek düzeye Osmanlılarda ulaşmıştır. Osmanlı dönemi ahşap ustaları Selçuklu ve Beylikler devri ustalarını takip ederek özellikle oyma, şebekeli oyma ve kündekâri (geçme) tekniklerinde en güzel eserler vermişlerdir. ${ }^{43}$ Osmanlı

Fazilet Koçyiğit, "Amasya'da Ahşap Tavanlı İki Cami Örneği: Şıhlar ve Kızılkışlacık Köyü Camileri”, Manas Sosyal Araştırmalar Dergisi, 8/2 (2019): 1641-1658. gisi, 37-45. (Erişim tarihi: 16.02.2021,) https://www.academia.edu/12508986/Do\%C4\%9Fu_Karadeniz_B\%C3\%B6lgesinde_Baz\%C4\%B1_Ah\%C5\%9Fap_Camiler. Halil İbrahim Eryılmaz, Türkiye'deki Il. Abdülhamid Camileri, (İstanbul: Kitabevi Yayınları, 2019), 227-240. İnci Kuyulu, "Bademli-Kılcızade Mehmet Ağa Cami (Ödemiş/ İzmir)", Vakıflar Dergisi, 24 (1994): 147-158. Aslı Büyükkal, "Antalya Yöresi Mimarisinde Ahşap Malzemenin Kullanımı", (Yüksek Lisans Tezi, Marmara Üniversitesi Sosyal Bilimler Enstitüsü, 2019), 115, 119.

36 Serkan Kılıç, “Elmalı'daki Ahşap Tavanlı Cami ve Mescitler (Osmanlı Dönemi)”, Mediterranean Journal of Humanities, 8/2 (2018): 407-425.

37 Mustafa Denktaş, "Pınarbaşı-Uzunyayladaki Ahşap Direkli Camiler", Erciyes Üniversitesi Sosyal Bilimler Enstitüsü Dergisi, 16 (2004/1): 54, 58. Mustafa Murat Bozcu, Burdur Ilinde Türk Mimarisi Selçuklu, Beylikler ve Osmanlı Eserleri, (Burdur: Burdur Ticaret ve Sanayi Odası Yayınları, 2013), 25, 62, 80. Özkan, “Gümüşhane'de Ahşap Tavanlı Camiler", 63-80. Selçuk Mülayim, Geometrik Süslemeler-Selçuklu Çağı, (Ankara: Kültür Bakanlığı Yayınları, 1982), 57.

41 Aktemur, "Türk Ahşap İşçiliği", 101.

42 Yücel, "Selçuklu Ağaç İşçiliği", Sanat Dünyamız, 4 (1975): 24.

43 Arseven, Türk Sanatı, 220; Yücel, "Ahşap”, 182. 
süslemelerinde rûmî ve palmet kompozisyonları ile birlikte bitkisel motiflerinin de ağırlık kazandığı dikkat çekmektedir. Beylikler dönemi ile Osmanlı Dönemi arasında geçiş sağlayan 15. yüzyıl eserlerinde bitkisel motiflerin yanında yazı ve geometrik motiflerle zenginleştirilmiş daha farklı bir kompozisyon programı görülmektedir. 16. yüzyıl ahşap işçiliğinde sonsuza açılan yıldızlar ile dikdörtgen biçimlerin yanı sıra, rûmîlerle daha karmaşık bir üslûba girerek bütün yüzeyi kaplayan bitkisel bezeme söz konusudur. Ahşap sanatında daha önce kullanılmayan çintemani motifi de kullanılmaya başlanmış, fildişi kakma yazı frizleriyle kompozisyon tamamlanmıştır. ${ }^{44}$ 17. yüzyıl ağaç işlerinde, orijinal durumlarından ayrılarak, stilizasyona doğru ilerleyen bitkisel motifler görülmeye başlanmıştır. Ana konuda sonsuzluk hâkimdir, ancak sâdelikten kısmen uzaklaşılmış; hareketli, göz doldurucu bezemeye doğru adım atılmıştır. ${ }^{45}$ 17- 18. yüzyıllarda Avrupa'nın Barok ve Rokoko üsluplarının etkisiyle ahşap işçiliğinde " $C$ " ve "S" kıvrımlı bitkisel bezemeler, natürmort kompozisyonlar ve çiçek demetleri görülmeye başlanmıştır. ${ }^{46}$ Bundan sonra ağaç işçiliği Türk karakterini kaybederek tamamen Avrupalılaşmış; artık eserleri İtalyan Barok, Fransız Rokokosundan ayırma imkânı hemen hemen ortadan kalkmıştır. 19. yüzyılda yine aynı Batılı akımların etkisiyle Türk mimarisinde, ışınsal bir yaklaşımla tasarlanmış rozet, istiridye motifleri ile natüralist üsluplu çiçek motifleri ağaç işçiliğinde de ortaya çıkarak sivil ve dini mimaride çoğunlukla kullanılır hale gelmiştir. ${ }^{47}$ 20. yüzyılda ise yıldız, dikdörtgen gibi önceki yüzyıllarda kullanılan geometrik motiflerin yanı sıra bitkisel, yazılı ve nesneli bezemeler kullanılmıştı.48

Görüldüğü gibi ahşap işçiliği, İslâm öncesi Türk sanatlarında erken örneklerini vermiş ve ilk dönemlerden itibaren İslâm ülkelerinin çoğunda büyük önem kazanmış bir sanat dalı olmuştur. Anadolu'da Selçuklularla gelişip kendine has bir nitelik kazanmış olan bu sanat, Osmanlılarda da zengin örneklerle yaygınlaştırılarak kullanılmış ve konumuz olan Demirci yöresindeki bazı camilerde de sevilerek uygulanmaya devam etmiştir.

\section{Demirci Küpeler Mahallesi Eski Camii}

Küpeler Mahallesi'nde bulunan eser, 8,47 x 10.00 m. ebatlarında derinlemesine dikdörtgen planlı bir yapıdır. Kuzey cephesinde bulunan kitabede verilen bilgiye göre ilk olarak H. 779 / M. 1377-78 yılında inşa edilen eser H. 1307 / M. 1889-90 yılında onarım görmüştür. Harimin kuzeyinde yer alan son cemaat mahalli, ah- 
şap direklerle üç açıklıklı bir düzenlemeye sahiptir. Örtü sistemi dıştan kırma çatı ile kaplanmış düz ahşap tavanla sağlanan yapıda çatı doğrudan caminin beden duvarlarına oturmaktadır. Cami 2020 yılında restorasyon geçirmiş olup henüz ibadete açılmamıştır.

Harim Tavan Göbeği: Harim, kuzey-güney doğrultusunda dikdörtgen tabana oturan, kirişlemesi alttan kaplamalı, tek kat bindirmeli tavanla örtülüdür.

Tavanın ortasında aplike tekniğinde, ahşap malzemeli, soyut bitkisel motiflerle süslenmiş, dairesel formlu (madalyon) bir göbek yer almaktadır. Bu süsleme tarzı Klasik Osmanlı mimarisinde hemen hemen tüm malzeme gruplarında görülen bir düzenlemedir. Göbek merkezinde ışınsal desenler ile onu çevreleyen bitkisel motifler yer almaktadır. Işınsal desenlerin etrafında ters-düz ' $C$ ' kıvrımlı biçimlerin yan yana birim tekrarının çiviler yardımı ile çakılmasıyla stilize bitkisel motifler oluşturulmuştur. Dairesel madalyon dış taraftan iki sıra sarı ve krem renkli baklava motifleriyle kuşatılmıştır. Böylelikle tavan ile tavan göbeği arasındaki sınır oluşmuştur. Bu bölümün dışında kalan kısımlar düz tavanla örtülüdür (Fotoğraf 1).

\section{Demirci Ahmetler Mahallesi Camii}

Ahmetler Mahallesi'nde bulunan eser, kuzey cephesinde bulunan kitabeye göre $\mathrm{H}$. 1187/ M. 1772-73 tarihinde inşa edilmiştir. Yapılan tadilat ve onarımlarla yapı doğu ve kuzey bölümlerde genişletilmiştir. Özgün haline göre eser 8,33 x 8,33 m ebatlarında kare planlı bir yapı iken günümüzde 13,73 x 10,97 m ebatlarında enine dikdörtgen planlıdır. Örtü sistemi dıştan kırma çatı ile kaplanmış düz tavanla sağlanan yapıda çatı doğrudan caminin beden duvarlarına oturmaktadır. Yığma taş strüktürlü caminin temelinde ve beden duvarlarında kaba yonu taş, muhdes duvarlarda betonarme, özgün yapının üst örtü sisteminde ise ahşap malzeme kullanılmıştır.

Harim Tavan Göbeği: Özgün harim, kare tabana oturan, kirişlemesi alttan kaplamalı, tek kat bindirmeli tavanla örtülüdür.

Tavan göbeği ilk bakışta sahte kündekâri hissi veren asimetrik düzende yerleştirilmiş bir süslemeden meydana gelmektedir. Çıtalarla birbirinden ayrılan çiçek ve yaprak formlarından meydana gelen süsleme çakma ve yapıştırma kündekâri görüntüsünü anımsatmaktadır. Göbeğin merkezinde oyma tekniği ile yapılmış ahşap bir kabara mevcuttur. Göbek, merkezde bulunan çiçek etrafında kare panoların diyagonal dizilmesiyle oluşan kompozisyondan ibarettir. Bu panoların merkezinde pembe renkli küçük çiçek motifleri, dört köşede ise sarı renkli, yeşil yapraklı natüralist üslupta çiçek desenleri görülmektedir. Kare çerçevenin köşelerinde de beyaz renkli ve ikişerli sarı renkli, yeşil yapraklı natüralist üslupta çiçek desenleri 
bulunmaktadır. Tavan göbeğini oyma süslemeli ince bir şerit ile dar bir bordür çevrelemektedir. Böylelikle düz tavan ile tavan göbeği arasındaki sınır oluşmaktadır. Bu bölümün dışında kalan kısımlar düz tavanla örtülüdür (Fotoğraf 2).

\section{Demirci Üşümüş Mahallesi Camii}

Üşümüş Mahallesi'nde bulunan cami, doğu cephesindeki harim giriş kapısı üzerinde yer alan tabelaya göre H. 1242/1826-27 tarihinde inşa edilmiştir. Eser 7,66 x 14,00 m ölçülerinde, derinlemesine dikdörtgen planlıdır. Örtü sistemi dıştan kırma çatı ile kaplanmış düz tavanla sağlanan yapıda çatı doğrudan caminin beden duvarlarına oturmaktadır. Yığma taş strüktürlü caminin temelinde ve beden duvarlarında kaba yonu taş, üst örtü sisteminde ise ahşap malzeme kullanılmıştır.

Harim Tavan Göbeği: Mahfil dışındaki harim alanın büyük bölümü, kare tabana oturan, kirişlemesi alttan kaplamalı, döner eksenli, beş kat bindirmeli tavanla örtülüdür. Mahfil ile harim tavan göbeği arasındaki alan ise düz tavanla örtülüdür.

Tavanın merkezinde iç içe üç kareden oluşan, ilk bakışta sahte kündekâri hissi veren çiçek ve yaprak formlarından meydana gelen çakma ve yapıştırma kündekâri ve oyma tekniği ile yapılmış tavan göbeği bulunmaktadır. Beşinci katta yer alan tavan göbeğinin merkezindeki daire içerisine etrafındaki ışınsal kollarla birlikte bir kabara motifi aplike edilmiştir. Daire ile zikzak motifleriyle bezenmiş kare bordür arasında kalan bölümler oyma çiçek ve yaprak motifleriyle doldurulmuştur. Dördüncü katta, baklava panolarının sonsuzluk izlenimi uyandıracak şekilde yan yana ve alt alta tekrarlanmasıyla oluşan bir kompozisyon yer almaktadır. Bu panoların merkezinde oyma tekniğiyle yapılmış çiçek desenleri görülmektedir. Zikzak motifli bordürlerin çevrelediği üçüncü katın köşebentlerinde oyma tekniğiyle yapılmış çiçek ve selvi motifleri yer almaktadır. İkinci katın köşebentleri ise çıtalar yardımıyla oluşturulmuş baklava şekilleriyle doldurulmuştur. Kalan diğer kısımlar düz tavanla örtülmüştür (Fotoğraf 3).

Kadınlar Mahfili Tavan Göbeği: Tavan göbeği düzgün bir kare biçiminde olup, en dışta, oyma tekniğiyle yapılmış baklava ve çiçek motifleriyle bezenmiş geniş bir bordür bulunmaktadır. Ortada, onikigen içerisinde oyma bir kabara mevcuttur. Bunun etrafında yine onikigenle çevrelenmiş, oyma tekniğinde stilize çiçek ve yaprak motifleri görülmektedir. Bu alanı da zikzak motifleriyle süslenmiş dar bir bordür çevrelemektedir (Fotoğraf 4).

\section{Demirci Köylüce Mahallesi Eski Camii}

Köylüce Mahallesi'nde bulunan cami, batı cephesinde yer alan kitabeye göre $\mathrm{H}$. 1292/ M. 1876-77 tarihinde inşa edilmiştir. 7,60 x 14,30 m ölçülerinde enine dik- 
dörtgen planlıdır. Örtü sistemi dıştan kırma çatı ile kaplanmış düz tavanla sağlanan yapıda çatı doğrudan caminin beden duvarlarına oturmaktadır. Yığma taş strüktürlü caminin temelinde ve beden duvarlarında kaba yonu taş, üst örtü sisteminde ise ahşap malzeme kullanılmıştır. Cami günümüzde kullanılmamaktadır.

Harim Tavan Göbeği: Harim, kirişlemesi alttan kaplamalı, eksenleri aynı doğrular üzerinde bulunan tavanla örtülüdür.

Harimin merkezinde bulunan ahşap tavan göbeği basit bir düzenleme ile yapılmıştır. Göbek dıştan, zikzak motifli, ince çıtalarla oluşturulan bir bordür ile bordür içinde, yine zikzak motiflerinin diyagonal sıralanmasıyla oluşan bir kompozisyon şeklindedir. Mavi zeminli göbekteki çıtalar sarı ve yeşil renklerle boyanarak kompozisyona hareketlilik kazandırılmıştır (Fotoğraf 5).

\section{Demirci Kerpiçlik Mahallesi Camii}

Kerpiçlik Mahallesi'nde bulunan eser, giriş kapısı üzerinde yer alan tabelaya göre 1882 yılında inşa edilmiştir. Yapının özgün hali 5,63 x 11,18 m ebatlarındadır. Derinlemesine dikdörtgen planlı bir yapı olan caminin kuzeyinde yer alan son cemaat mahalli sonradan yapılmıştır. Örtü sistemi dıştan kırma çatı ile kaplanmış düz tavanla sağlanan yapıda çatı doğrudan caminin beden duvarlarına oturmaktadır. Yığma taş strüktürlü caminin temelinde ve beden duvarlarında kaba yonu taş, üst örtü sisteminde ise ahşap malzeme kullanılmıştır.

Harim Tavan Göbeği: Harim, kirişlemesi alttan kaplamalı, tek kat bindirmeli tavanla örtülüdür.

Sekizgen şekilli tavan göbeği ilk bakışta sahte kündekâri hissi veren simetrik düzende yerleştirilmiş bir süslemeden meydana gelmektedir. Köşelerinde baklava motifi bulunan bir kare içerisinde yer alan göbek, merkezinde stilize çiçek motifinin yer aldığı geometrik formlardan meydana gelmektedir. Göbek süslemeleri çıtalarla birbirinden ayrılarak çakma ve yapıştırma kündekâri görüntüsünü anımsatmaktadır. Göbeğin merkezinde oyma tekniğiyle yapılmış altı adet çiçek motifinin yer aldığı beyaz zeminli bir daire bulunmaktadır. Dairenin etrafını saran sekizgen alan, sonsuzluk izlenimi verecek şekilde, ortasında çiçek motifinin yer aldığı turuncu, yeşil ve kahverengi renkli, diyagonal altıgenlerle doldurulmuştur. Beyaz zeminli köşebentlerin merkezinde birer adet çiçek motifi bulunmakta iken bugün çiçeklerin bulunduğu yerlere dekoratif amaçlı birer ampul takılmıştır. Karenin köşelerinde birer adet iç içe baklava deseni bulunmaktadır. Tavan göbeğini en dışta zikzak süslemeli ince bir bordür çevrelemektedir. Böylelikle düz tavan ile tavan göbeği arasındaki sınır oluşmaktadır. Bu bölümün dışında kalan kısımlar düz tavanla örtülüdür (Fotoğraf 6). 


\section{Demirci Ahatlar Mahallesi Camii}

Ahatlar Mahallesi'nde bulunan cami, doğu cephesindeki giriş kapısı üzerinde yer alan tabelaya göre 1885 tarihinde inşa edilmiştir. Eser 7,75 x 10,07 m ölçülerinde, derinlemesine dikdörtgen planlıdır. Harimin doğusunda muhdes hazırlık mekânı yer almaktadır. Örtü sistemi dıştan kırma çatı ile kaplanmış düz tavanla sağlanan yapıda çatı doğrudan caminin beden duvarlarına oturmaktadır. Yığma taş strüktürlü caminin temelinde ve beden duvarlarında kaba yonu taş, muhdes mekânda ve üst örtü sisteminde ise betonarme malzeme kullanılmıştır.

Harim Tavan Göbeği: Yapılan onarımlar sırasında caminin tavanı yenilendiği için orijinal tavan göbeği muhdes mekânın kuzey duvarında bulunmaktadır. Taklit kündekâri ve oyma tekniklerinin kullanıldığı tavan göbeğinde ok uçlarından oluşan baklava motiflerinin, sonsuzluk izlenimi uyandıracak şekilde, yan yana ve alt alta tekrarlanmasıyla oluşan bir kompozisyon yer almaktadır. Bu panoların merkezinde oyma tekniğiyle yapılmış stilize çiçek desenleri görülmektedir. Tavan göbeğini sade bir bordür sonlandırmaktadır (Fotoğraf 7).

\section{Demirci Söğütçük Mahallesi Camii}

Söğütçük Mahallesi bulunan eser, 12,78 x 15,00 m ebatlarında boyuna dikdörtgen planlı bir yapıdır. Doğu cephesindeki kitabeye göre yapı 1887 tarihinde inşa edilmiştir. Harimin kuzeyinde yer alan son cemaat mahalli, doğu cephesinde yer alan tabelalara göre 1963 yılında yapılmıştır. Bu esnada caminin örtü sistemi de yenilenmiştir. ${ }^{49}$ Örtü sistemi dıştan kırma çatı ile kaplanmış düz tavanla sağlanan yapıda çatı doğrudan caminin beden duvarlarına oturmaktadır. Yığma taş strüktürlü caminin temelinde ve beden duvarlarında kaba yonu taş, üst örtü sisteminde ise ahşap malzeme kullanılımıştır. Muhdes son cemaat mahalli betonarme yapılıdır.

Harim Tavan Göbeği: Mahfil dışındaki harim alanı, kare tabana oturan kirişlemesi alttan kaplamalı, döner eksenli, üç kat bindirmeli tavanla örtülüdür. Kadınlar mahfili ise düz tavanla örtülüdür.

Tavanın merkezinde iç içe üç kareden oluşan, ilk bakışta sahte kündekâri hissi veren çiçek ve yaprak formlarından meydana gelen çakma ve yapıştırma kündekâri ve oyma tekniği ile yapılmış tavan göbeği bulunmaktadır. Tavan göbeğinde taklit kündekâri, aplike, çıtakâri ve oyma teknikleri birlikte kullanılmıştır. Tavanın merkezinde aplike tekniğiyle, stilize bitkisel motiflerle oluşturulmuş bordürlerle 
çevrili, iç içe üç kareden oluşan tavan göbeği bulunmaktadır. Üç katın köşelerine yine aplike tekniği ile oluşturulan stilize çiçek motifleriyle doldurulmuş çeyrek daireler yerleştirilmiştir. Tavan göbeğinin tam merkezinde aplike tekniğiyle oluşturulmuş bitkisel desenli sekizgen içerisinde, etrafı ince çıtalarla çerçevelenmiş, yine aplike tekniğiyle içi oyularak stilize bitkisel motiflerle doldurulmuş sekiz kollu iri bir yıldız yer almaktadır. Üçüncü katın merkezdeki bu yıldız ile yıldızı çevreleyen sekizgen arasındaki boşluklar sonsuzluk izlenimi verecek şekilde, çıtalar yardımıyla oluşturulan karelerle doldurulmuştur. Sekizgen ile kare arasında bulunan sarı zeminli üçgen bölümler boş bırakılmıştır. Aplike tekniğiyle, oluşturulmuş iki kare bordür arasında kalan bölümlere ise taklit kündekâri tekniğiyle dikdörtgen plakalar yerleştirilmiştir. İkinci katı oluşturan karenin köşebentlerine, sonsuzluk izlenimi verecek şekilde taklit kündekâri tekniğiyle dikdörtgen plakalar yerleştirilmiştir. En dıştaki bitkisel bordürle çevrelenmiş birinci katı oluşturan karenin köşebentlerinde de ortasında çiçek motifi bulunan karenin etrafına dikdörtgenlerin yatay ve dikey yerleştirilmesiyle oluşturulmuş taklit kündekâri tekniğiyle yapılmış bir kompozisyon yer almaktadır (Fotoğraf 8).

\section{Demirci Sevinçler Mahallesi Eski Camii}

Sevinçler Mahallesi'nde bulunan cami, doğu cephesinde yer alan tabelaya göre H. 1303/ M. 1887-88 tarihinde inşa edilmiştir. Eser 9,27 x 9,51 m ölçülerinde, kareye yakın dikdörtgen planlıdır. Harimin doğusunda muhdes hazırlık mekânı yer almaktadır. Örtü sistemi dıştan kırma çatı ile kaplanmış düz ahşap tavanla sağlanan yapıda çatı doğrudan caminin beden duvarlarına oturmaktadır. Caminin beden duvarlarında kabayonu taş ve kerpiç malzeme kullanılmıştır. Cami günümüzde kullanılmamaktadır.

Harim Tavan Göbeği: Harim, kirişlemesi alttan kaplamalı, tek kat bindirmeli tavanla örtülüdür.

Taklit kündekâri ve çıtakâri tekniğinde yapılmış sekizgen şekilli tavan göbeği, köşelerinde altı köşeli yıldız (Mühr-i Süleyman) motifi bulunan bir kare içerisinde yer almaktadır. Göbeğin merkezinde, çıtakâri tekniğiyle, zikzak desenleriyle oluşturulan başka bir sekizgen, bu sekizgenin merkezinde de ortadaki bir altıgen yıldız şekli etrafında gelişen damlacıkların radyal dizilişi ile oluşturulmuş sekiz yapraklı iri bir çiçek motifi yer almaktadır. İki sekizgen arasına yan yana sıralanmış tek sıra baklava motiflerinden oluşturulan ince bir bordür yerleştirilmiştir. Tavan göbeğini en dışta zikzak süslemeli ince bir kare bordür çevrelemektedir. Bu bölümün dışında kalan kısımlar ise düz tavanla örtülüdür (Fotoğraf 9). 


\section{Demirci Esenyurt Mahallesi Camii}

Esenyurt Mahallesi'nde bulunan cami, doğu cephesindeki giriş kapısı üzerinde yer alan tabelaya göre 1889 tarihinde inşa edilmiştir. Eser 8,26 x 11,46 m ölçülerinde, derinlemesine dikdörtgen planlıdır. Harimin doğusunda muhdes hazırlık mekânı yer almaktadır. Örtü sistemi dıştan kırma çatı ile kaplanmış düz tavanla sağlanan yapıda çatı doğrudan caminin beden duvarlarına oturmaktadır. Yığma taş strüktürlü caminin temelinde ve beden duvarlarında kaba yonu taş, muhdes mekânda ise betonarme malzeme kullanılmıştır.

Harim Tavan Göbeği: Mahfil dışındaki harim alanı, dörtgen tabana oturan, kirişlemesi alttan kaplamalı, döner eksenli, üç kat bindirmeli tavanla örtülüdür. Her katta soyut bitkisel motiflerin dendanlı şeklinde yan yana birim tekrarının çiviler yardımı ile çakılmasıyla ahşap kenarlıklar oluşturulmuştur. Kadınlar mahfili ise harim alanından farklı olarak düz tavanla örtülüdür.

Tavan göbeği ilk bakışta sahte kündekâri hissi veren simetrik düzende yerleştirilmiş bir süslemeden meydana gelmektedir. Çiçek ve yaprak formlarından meydana gelen süsleme çıtalarla birbirinden ayrılarak çakma ve yapıştırma kündekâri görüntüsünü anımsatmaktadır.

Tavan göbeği taklit kündekâri ve aplike tekniği ile yapılmış, iç içe üç adet kareden oluşmaktadır. Göbeğin merkezinde barok üsluplu stilize bitkisel desenlerle doldurulmuş daire biçimli madalyon yer almaktadır. Üçüncü kat tavanın madalyon dışındaki yüzeyi, ince çıtalarla, aralarında küçük kareler oluşturacak şekilde, sepet örgüsü biçiminde düzenlenmiş bir taksimat sergilemektedir. Küçük karelerin bir kısmında çiçek motifi bulunmaktadır. İkinci katı oluşturan karenin köşebentleri ise ortasında çiçek motifinin yer aldığı iç içe üçgenlerle doldurulmuştur. Birinci katı oluşturan karenin köşebentleri ise merkezinde, sonsuzluk izlenimi veren çiçek motifli altıgenlerin yer aldığı iç içe üçgenlerle doldurulmuştur. Geri kalan tavan yüzeyinde ise ince çıtaların birbirine verev ve yatay olarak yerleştirilmesiyle oluşturulan küçük baklava dilimli geometrik kompozisyon bulunmaktadır (Fotoğraf 10).

\section{0. Çandır Mahallesi Camii}

Çandır Mahallesi'nde bulunan cami, harim giriş kapısı üzerinde yer alan kitabeye göre H. 1325 / M. 1909-10 tarihinde inşa edilmiştir. Eser 7,21 x 9,27 m ölçülerinde, derinlemesine dikdörtgen planlıdır. Harimin kuzeyinde muhdes hazırlık mekânı yer almaktadır. Örtü sistemi dıştan kırma çatı ile kaplanmış düz tavanla sağlanan yapıda çatı doğrudan caminin beden duvarlarına oturmaktadır. Caminin beden duvarlarında yığma taş, muhdes mekânda ise betonarme malzeme kullanıımışıı. 
Harim Tavan Göbeği: Mahfil dışındaki harim alanı, dörtgen tabana oturan, kirişlemesi alttan kaplamalı, döner eksenli, üç kat bindirmeli tavanla örtülüdür. Kadınlar mahfili ise düz tavanla örtülüdür.

Tavanın merkezinde iç içe üç kareden oluşan, ilk bakışta sahte kündekâri hissi veren, merkezinde çiçek formlarının yer aldığı çakma-yapıştırma kündekâri ve oyma tekniğiyle yapılmış tavan göbeği bulunmaktadır. Tavan göbeği taklit kündekâri, aplike ve oyma tekniği ile yapılmış, iç içe üç adet kareden oluşmaktadır. Göbeğin merkezinde stilize bitkisel desenlerle doldurulmuş altıgen biçimli bir madalyon yer almaktadır. Üçüncü kat tavanın madalyon dışındaki yüzeyinde ortalarında çiçek motifi bulunan, ince çıtaların birbirine yatay ve dikey olarak yerleştirilmesiyle oluşturulmuş çokgen ve dikdörtgen biçimli geometrik kompozisyon bulunmaktadır. Bu alanın etrafını aplike tekniğiyle oluşturulmuş stilize bitkisel motiflerden bir bordür çevrelemektedir. İkinci katı oluşturan karenin köşebentlerine ise baklava motifleriyle doldurulmuş birer üçgen yerleştirilmiştir. Birinci katı oluşturan kare alan, ince çıtalarla aralarında küçük kareler oluşturacak şekilde, sepet örgüsü biçiminde düzenlenmiş bir taksimat sergiler. Küçük karelerin içinde çiçek motifi bulunmaktadır. Geri kalan tavan yüzeyinde ise ince çıtaların birbirine yatay ve verev olarak yerleştirilmesiyle oluşturulan küçük baklava dilimli geometrik kompozisyon bulunmaktadır (Fotoğraf 11).

\section{Demirci Kuloğlu Camii}

Merkez Hacı Hamza Mahallesi'nde bulunan eser, 9,60 x 9,81 m ebatlarında, kareye yakın dikdörtgen planlı bir yapıdır. Eserin kesin inşa tarihi bilinmemektedir. Örtü sistemi dıştan kırma çatı ile kaplanmış düz ahşap tavanla sağlanan yapıda çatı doğrudan caminin yığma taş strüktürlü beden duvarlarına oturmaktadır. Harimin doğusunda muhdes hazırlık mekânı yer almaktadır. En sonu 2020 yılında olmak üzere, yapılan restorasyon çalışmalarıyla caminin özgün yapısı büyük değişikliğe uğramıştır.

Harim Tavan Göbeği: Harim, kirişlemesi alttan kaplamalı, tek kat bindirmeli tavanla örtülüdür. Orijinal ahşap tavan yakın zamanda yenilenen tavan örtüsünün altında kalmıştır.

İlk bakışta sahte kündekâri hissi veren asimetrik düzende yerleştirilmiş bir süslemeden meydana gelmektedir. Çiçek formlarından meydana gelen süsleme çıtalarla birbirinden ayrılarak çakma ve yapıştırma kündekâri görüntüsünü anımsatmaktadır. Tavan yüzeyine göre çökertilmiş olan sekizgen göbeğin merkezinde oyma ahşap bir kabara motifi, bunun etrafında da içlerinde çiçek motifi yerleştirilmiş altıgen ve baklava motifleri bulunmaktadır. Bunun etrafını, oyma 
tekniğiyle bezenmiş bir bordür çevrelemektedir. Sekizgenin iki köşesine içinde çiçek motifi bulunan üçgenler yerleştirilmiştir. İçteki sekizgen ile düz-ters üçgen motiflerle bezenmiş beyaz zeminli bordürün arası, sonsuzluk ifade edecek şekilde, ortalarında oyma tekniğinde çiçek motifleri bulunan kare ve baklava motifleriyle doldurulmuştur. Göbeği çevreleyen dışta taraftaki beyaz zeminli içbükey alan boş bırakılmıştır. En dıştaki köşebentlere ise ortasında çiçek motifi bulunan üçgenler yerleştirilmiştir. Göbek kompozisyonu en dış kısımda zikzak şekilli ince bir bordürle çevrelenerek düz tavan ile sınır oluşturulmuştur (Fotoğraf 12).

\section{Demirci Boyacık Mahallesi Eski Camii}

Boyacık Mahallesi'nde bulunan eser 8,03 x 7,68 m ebatlarında, enine dikdörtgen planlı bir yapıdır. Yapım tarihi tam olarak bilinmemektedir. Örtü sistemi dıştan kırma çatı ile kaplanmış düz tavanla sağlanan yapıda çatı, doğrudan caminin beden duvarlarına oturmaktadır. Yığma taş strüktürlü caminin temelinde ve beden duvarlarında kaba yonu taş, son cemaat mahallinde bağdadi duvar, üst örtü sisteminde ise ahşap malzeme kullanılmıştır. Cami günümüzde kullanılmamaktadır.

Harim Tavan Göbeği: Harim, kirişlemesi alttan kaplamalı, tek kat bindirmeli tavanla örtülüdür.

Harimin merkezinde bulunan ahşap tavan göbeği basit bir düzenlemeye sahiptir. Harim tavanının ortasında bulunan göbek, ahşap malzemeden, oyma, çıtakâri ve aplike tekniğiyle yapılmıştır. Göbek merkezinde ince çıtalarla vasıtasıyla kare içine alınmış bir kabara motifi ile bu motiften çıkan ışınsal desenler yer almaktadır. Tavan göbeğini en dışta yumurta frizli ve baklava motifli ince bir bordür çevrelemektedir. Tavan göbeği ile bordür arası ince çıtalarla oluşturulan üçgen motifleriyle doldurulmuştur. Göbek dışındaki tavan örtüsünde ise çıtalar yardımıyla oluşturan iç içe kareler şeklinde bir kompozisyon görülmektedir (Fotoğraf 13).

\section{Demirci Kuzeyir Mahallesi Eski Camii}

Kuzeyir Mahallesi bulunan eser 10,73 x 7,81 m ebatlarında, enine dikdörtgen planlı bir yapıdır. Kesin inşa tarihi bilinmemektedir. Örtü sistemi dıştan kırma çatı ile kaplanmış düz tavanla sağlanan yapıda çatı doğrudan caminin beden duvarlarına oturmaktadır. Harimin batısında yer alan son cemaat mahalli, sonradan yapılmıştır. Yığma taş strüktürlü caminin temelinde ve beden duvarlarında kaba yonu taş, üst örtü sisteminde ise ahşap malzeme kullanılmıştır. Cami günümüzde kullanılmamaktadır.

Harim Tavan Göbeği: Harim, kirişlemesi alttan kaplamalı tavanla örtülüdür. 
İlk bakışta sahte kündekâri hissi veren simetrik düzende yerleştirilmiş bir süslemeden meydana gelmektedir. Çiçek formlarından meydana gelen süsleme çıtalarla birbirinden ayrılarak çakma ve yapıştırma kündekâri görüntüsünü anımsatmaktadır. Ahşap tavan göbeğinde hasır örgü motifi bulunmaktadır. Ortalarında oyma teknikleriyle oluşturulmuş çiçek motifi bulunan bu kompozisyon, aynı süslemenin sonsuzluk izlenimi uyandıracak şekilde diyagonal olarak tekrarlanmasıyla meydana gelmiştir. Göbeğin doğu tarafında çıtakâri tekniğinde, merkezi daireden giderek yayılan ışınsal kollarla çevrelenmiş güneş şekilli yelpaze tavan uygulaması yer almaktadır. Göbeğin batı tarafında ise çıtalar yardımıyla oluşturulmuş iç içe baklava desenleri görülmektedir (Fotoğraf 14).

\section{Değerlendirme ve Sonuç}

Gerilme gücü taştan daha üstün, daha hafif ve işlenmesinin daha kolay olması nedeniyle ahşap, tarih boyunca hem camilerde hem de sivil sivil mimari örneklerinde çok fazla tercih edilen bir malzeme olmuştur. Ahşap malzeme küçük, mütevazı binalarda, özellikle örtü ve taşıyıcı unsur olarak yoğun bir şekilde kullanılmışır. ${ }^{50}$

Tanımladığımız tavan göbekleri hakkında genel bir değerlendirme yaparsak, Demirci camilerinde on dört adet orijinal tavan göbeğine rastlanmıştır. Kirişlemesi alttan kaplamalı olan bu tavan göbeklerini biçim bakımından kiriş ve bindirmeleri paralel olanlar ve kirişleri köşeli birleşenler olarak ikiye ayırmak mümkündür. Kirişleri köşeli birleşen tavanları da döner eksenli ve iç içe bindirmeli olarak ikiye ayırabiliriz. Köylüce ve Kuzeyir mahalle camileri kiriş ve bindirmeleri paralel olanlardandır. Çankırı Sakarca Köyü Camii (19. yüzyıl) ${ }^{51}$ Çankııı Yeni Camii ${ }^{52}$, Çanakkale, Kayserili Ahmed Paşa Camii (19. yüzyıl) ${ }^{53}$ de benzer düzenlemeye sahiptir (Tablo 1). Kirişleri köşeli birleşen döner eksenli tavanlara göbeklerine Üşümüş, Esenyurt, Çandır ve Söğütçük Mahalle camilerinin tavan göbekleri örnek verilebilir. Bu eserlerde görülen tavan göbeklerine benzer bir düzenleme, Sivrihisar Akdoğan Mescidi (15. yüzyıl) ${ }^{54}$, Trabzon, Çaykara, Akköse ${ }^{55}$, Amasya, Belmebük Köyü Camii, Amasya Dadı Köyü Camii, Merzifon, Hanife Hatun camilerinde de görülmekte-

Aktemur, "Türk Ahşap İşçiliği", 103; Kuran, Anadolu'da Ahşap Sütunlu Selçuklu Mimarisi, 172.

51 Özlem Aktaşcı, "Çankırı/Kızılırmak Sakarca Köyü Camisi”, Akademi Sosyal Bilimler Dergisi, 6/16 (2019): 1-18.

52 http://www.mustafacambaz.com/details.php?image_id=39170\&sessionid=fcd6bdf0a7c030d5667b39e4f673b727 (Erişim tarihi: 21.03.2021). Yıllığı, 15/23 (2017): 61-92. gisi, 4/32 (Kasım 2016): 1-11.

55 Haşim Karpuz, “Doğu Karadeniz Bölgesinde Bazı Ahşap Camiler”, 44. 
dir (Tablo 2). ${ }^{56}$ Kirişleri köşeli birleşen iç içe bindirmeli tavanlara göbeklerine ise Küpeler, Ahmetler, Boyacık, Kerpiçlik, Sevinçler ve Kuloğlu camilerinin tavan göbekleri örnek verilebilir. İstanbul, Beşiktaş Kaptan İbrahim Ağa Camiii ${ }^{57}$, Merzifon, Ortaova Köyü, Amasya, İpekköy Camii, Merzifon, Yeşilören Köyü Camii ve Muğla Ulu Camii58 de iç içe bindirmeli tavan göbeklerine sahip camilerdendir (Tablo 3). ${ }^{59}$

Tarihlendirme açısından ele aldığımızda tavan göbeklerinin camilerin inşa edildiği zaman diliminde yapı ile birlikte yapıldıkları söylenebilir. Birbirine benzer özellikler taşıyan Esenyurt Mahalle Cami tavan göbeği 19. yüzyılın sonu ve Çandır Mahalle Cami tavan göbeği 20. yüzyılın başında yapılmıştır. Küpeler mahallesi ve Söğütçük mahalle camilerinde yapılan onarımlarda tavan göbekleri de yenilenmiş̧ir. Buna göre en son Söğütçük Mahallesi Camii tavan göbeği (19631966 yılları arasında) yapılmıştır.

Yöre camilerinde görülen tavan göbeklerinin hepsi ahşap malzemeden; taklit kündekâri, aplike, oyma ve çıtakâri teknikleri kullanılarak yapılmıştır. Köylüce Mahallesi Eski Camii tavan göbeği, sözünü ettiğimiz diğer tavan göbeklerine göre oldukça basit bir düzenlemeye sahiptir. Söğütçük Mahallesi Camii tavan göbeği ise incelediğimiz göbeklerin içerisinde en gösterişli olanıdır. Burada aplike tekniği ile çıkarılmış parçaların yüzeye yerleştirildiği görülmektedir.

Motif ve kompozisyon bakımından, göbek yüzeylerine uygulanan bezemeleri bitkisel ve geometrik motifler şeklinde ikiye ayırabiliriz. Ahmetler, Ahatlar, Üşümüş, Kuloğlu, Esenyurt, Çandır, Kerpiçlik, Kuzeyir ve Söğütçük camilerinin tavan göbeklerinde çoğunluğunu çiçek motiflerinin oluşturduğu bitkisel motifler görülmektedir. Bu motifler genellikle geometrik desenlerin içini doldurmak için kullanılmıştır. Küpeler Mahallesi Camii tavan göbeğinde ise madalyon içerisinde stilize bitkisel motifler yer almaktadır. Benzer süslemeye Amasya, Kızılkışlacık Köyü Camii tavan göbeğinde de rastlanmaktadır (Tablo 4).

Geometrik motifler bitkisel motiflere göre çok daha fazladır ve çoğunlukla taklit kündekâri tekniğiyle oluşturulan göbeklerde kullanılmıştır. Baklava, üçgen, kare,

Neslihan Korkmaz, "Amasya Camilerinde Ahşap Bindirme Tavan", (Doktora Tezi, Anadolu Üniversitesi, Sosyal Bilimler Enstitüsü, 2016), 68-91.

Eryılmaz, Türkiye'deki Il. Abdülhamid Camileri, 187-188.

http://www.akmb.gov.tr/userfiles/files/\%C4\%BOLLER\%20VE\%20ULU\%20CAM\%C4\%B0LER\%C4\%B0/MU\%C4\%9ELA/MU\%C4\%9ELA\%20ULU\%20CAM\%C4\%B0\%C4\%B0/MU\%C4\%9ELA\%20ULU\%20CAM\%C4\%B0\%C4\%B0.pdf (Erişim tarihi 21.03.2021).

Neslihan Korkmaz, "Amasya Camilerinde Ahşap Bindirme Tavan”, 91-107. 
dikdörtgen, madalyon ${ }^{60}$, çokgen, yıldız, mühr-i Süleyman ${ }^{61}$, zikzak, ok başı ve hasır örgü motifleri uygulanan geometrik motiflerdir. Figürlü ve nesneli motiflere ise hiç yer verilmemiştir. Kuloğlu, Boyacık, Esenyurt, Çandır, Kuzeyir, Sevinçler ve Söğütçük cami tavanlarında yer alan baklava, üçgen, kare, sekizgen motifleri Muğla Ulu camii ${ }^{62}$ ve Konya Hacı Hasan Camii tavan göbeklerinde ${ }^{63}$; yıldız motifi ise Anadolu Hisarı Camii (1885), İstanbul Makbul İbrahim Paşa Camii64, Aksaray Eskil Ulu Camii ${ }^{65}$, Kocaeli Derbent Hikmetiye Camii(1889) ${ }^{66}$, Konya Hacı Hasan Camii ve Kastamonu Çaycevher Köyü Cami ${ }^{67}$ ve Elmalı Toklular Mescidi ${ }^{68}$ ve Günalan Köyü Lengüme Cami tavan göbeğinde de görülmektedir (Tablo 5) ${ }^{69}$

Sonuç olarak Demirci'de ahşabın bu kadar çok kullanılmış olması bölgenin ormanlık bir alana sahip olmasına bağlamak mümkündür. Herhangi bir araştırma konusu olmayan yöre camileri, ahşap tavanlı camilerin Anadolu'daki geç dönem örnekleri arasında yer almaktadır. Ahşap tavan göbekleri, mahalli sanatçıların özel becerilerini ortaya koyması ve geleneksel ahşap mimarisinin taşradaki şaşırtıcı örnekleri olması bakımından oldukça önemlidir. Tespit edilen ahşap tavan

Kare, adaletin sembolü sayılmış, ateş, hava, su ve yer ile ilişkilendirilmiş, özellikle yeryüzünün değişmez sembolü olmuştur. Dikdörtgen, din, ilim, adalet ve hakikati; sekizgen, sonsuzluğu temsil etmiş̧tir. Daire (madalyon), Allah'a varış, gökyüzü ve sonsuzluk sembolü sayılmış, evrendeki düzeni, birliği ve bütünlüğün ifadesi kabul edilmiştir. Bkz. Ahmet Çaycı, İslam Mimarisinde Anlam ve Sembol, (Konya: Palet Yayınları, 2017), 66-71; Beşir Ayvazoğlu, Aşk Estetiği, (İstanbul: Ötüken Yayınları, 2000), 121.

61 i̇ç içe iki üçgenden meydana gelmiştir. Hz. Süleyman (as)a isnat edilerek "Mühr-i Süleyman" olarak isimlendirilmiştir. Nazara karşı etkiyi iki kat arttıran iki gözü tasvir etmektedir. Bundan dolayı, hastaları iyi etmek ve insanları kötü gözlerden koruma gücüne sahip bir tılsım olarak da kabul edilmiştir. Ayrıca tarih boyunca pek çok millet ve kültür tarafından bereket, bolluk ve güç sembolü olarak algılanmış ve kullanılmıştır. Bkz. Halil İbrahim Eryılmaz, Türk İslâm Sanatları II, (Ankara: Gazi Yayınları, 2020), 90; İskender Pala, Mühr-i Süleyman, Diyanet İslâm Ansiklopedisi, 31, (İstanbul: Diyanet İslâm Ansiklopedisi, 2006), 524-526; C. E. Arseven, Türk Sanatı, (İstanbul: Duran Ofset Basımevi: 1970), 206.

62 http://www.akmb.gov.tr/userfiles/files/\%C4\%BOLLER\%20VE\%20ULU\%20CAM\%C4\%B0LER\%C4\%B0/MU\%C4\%9ELA/MU\%C4\%9ELA\%20ULU\%20CAM\%C4\%B0\%C4\%B0/MU\%C4\%9ELA\%20ULU\%20CAM\%C4\%B0\%C4\%B0.pdf (Erişim tarihi 21.03.2021).

63 http://www.mustafacambaz.com/details.php?image_id=19875 (Erişim tarihi: 21.03.2021).

64 https://www.mustafacambaz.com/details.php?image id=37538 (Erişim tarihi: 21.03.2021).

65 Bekir Deniz, "Aksaray'da (Niğde) Ahşap Sütunlu İki Köy Cami", Arkeoloji-Sanat Dergisi, 4/4 (1988): 19-56.

66 http://www.mustafacambaz.com/details.php?image id=31369 (Erişim tarihi: 21.03.2021).

67 Aynur Durukan, "Safranbolu'daki Ahşap Tavanlı Camiler", I. Ulusal Tarih Içinde Safranbolu Sempozyumu (4-6 Mayıs 1999) Bildirileri Kitabı, (Yy: yy, 2003), 23-58.

68 Kılıç, “Elmalı'daki Ahşap Tavanlı Cami ve Mescitler (Osmanlı Dönemi)”, 414.

69 Burcu Karaca, "Burdur ve Çevresinde Bulunan Camilerin Ahşap Üzerine Kalemişi Süslemeleri", (Yüksek Lisans Tezi, Süleyman Demirel Üniversitesi, Isparta, 2017), 143. 
göbeklerinin tümünün Osmanlı Dönemi sonu ve Cumhuriyet Dönemi'ne tarihlendikleri ve yapımlarının 1960'lı yılların ortalarına kadar sürdürüldüğü söylenebilir. Tavan göbeği örneklerinin farklı olması her bölgenin kendine has bir üslubunun var olduğunu ortaya koymaktadır.

Günümüzde bir kısmı harap bir halde bırakılarak kaderine terk edilen bu ahşap tavanların döşeme ve süsleme elemanı olmasının yanında, bir kültür mirası olduğu da unutulmamalıdır. Bu değerli eserlerin korunması ve kayıtlara geçmesi yönünde çalışmalar hızla yapılmalıdır.

Tablo 1. Kiriş ve bindirmeleri paralel olan tavan göbek örnekleri.

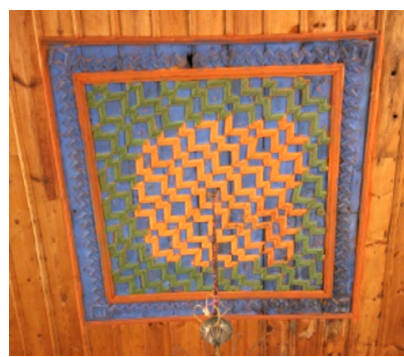

Köylüce Mahallesi Eski Camii

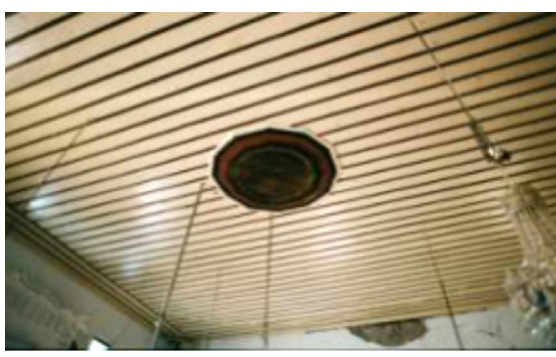

Çankırı Sakarca Köyü Camii

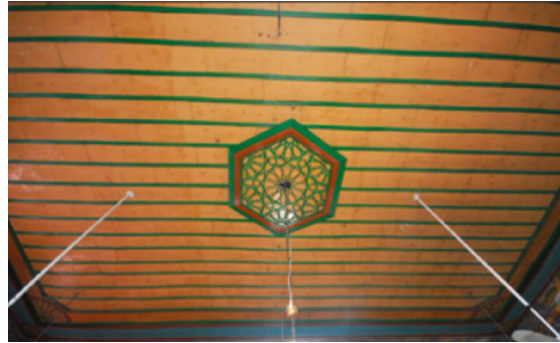

Çankırı Yeni Camii

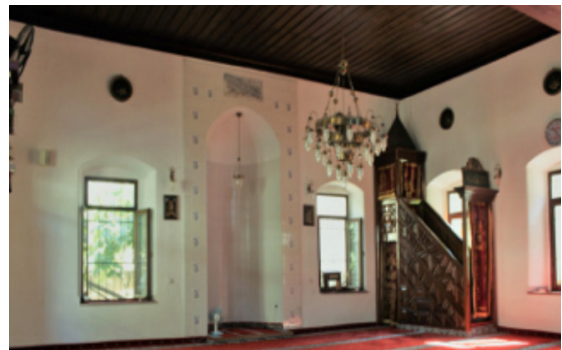

Çanakkale Kayserili Ahmed Paşa Camii

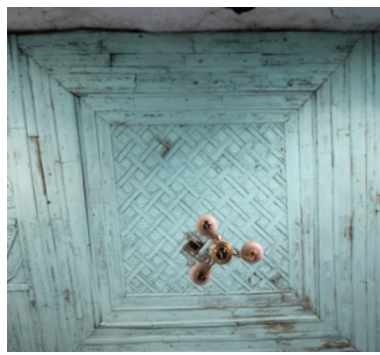

Kuzeyir Mahallesi Eski Camii 


\section{MÎZÂNÜ'L-HAK}

ISLAMI ILIMLER DERGISI

Tablo 2. Döner eksenli tavan göbek örnekleri

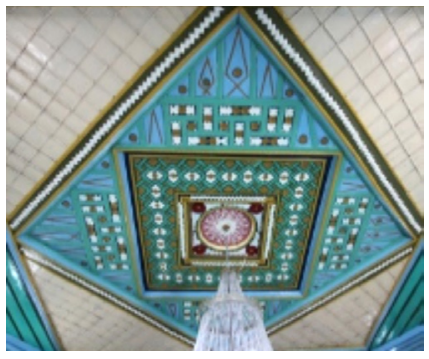

Üşümüş Mahallesi Camii

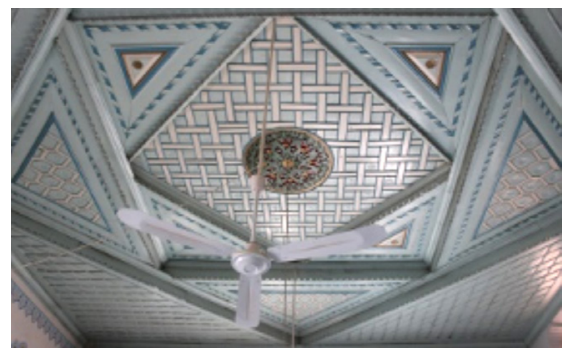

Esenyurt Mahallesi Camii

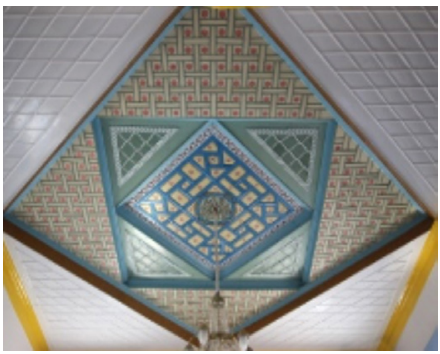

Çandır Mahallesi Camii

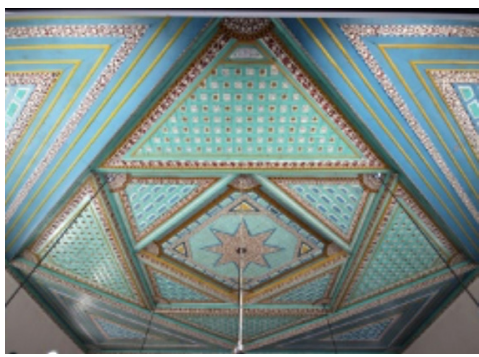

Söğütçük Mahallesi Camii

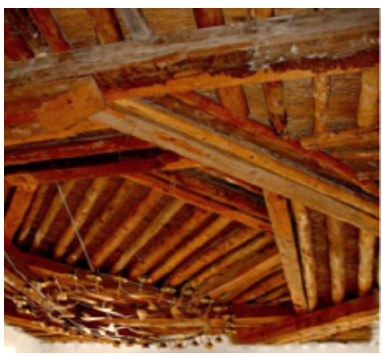

Sivrihisar Akdoğan Mescidi

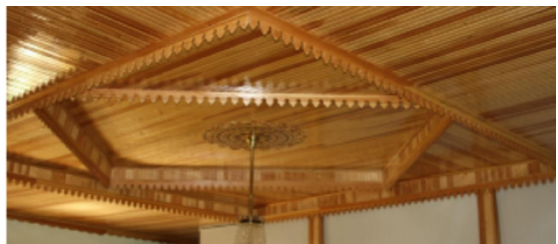

Amasya Belmebük Köyü Camii

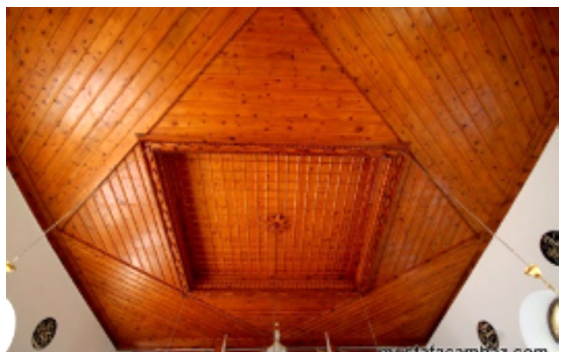

Kocaeli Derbent Hikmetiye Camii

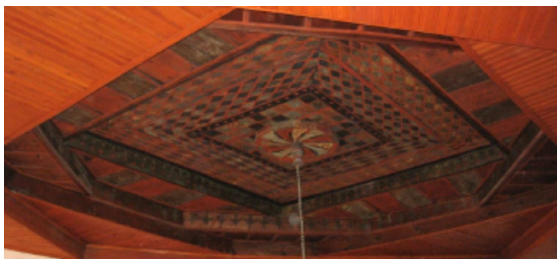

Merzifon Hanife Hatun Camii 
Halil İbrahim ERYILMAZ

Demirci Camilerindeki Ahşap Tavan Göbekleri

Tablo 3. Iç̧ içe bindirmeli tavan göbek örnekleri.

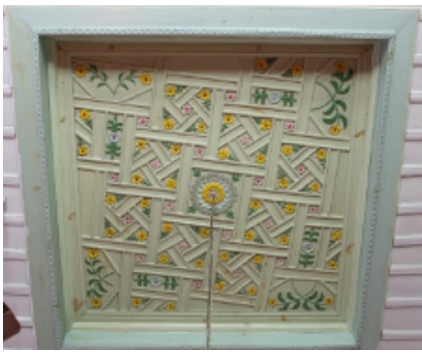

Ahmetler Mahallesi Camii

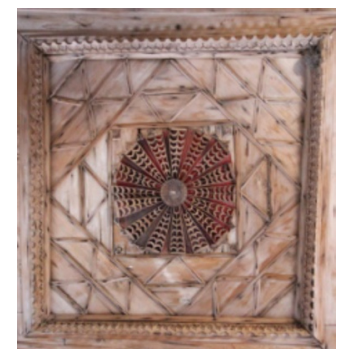

Boyacık Mahallesi Eski Camii

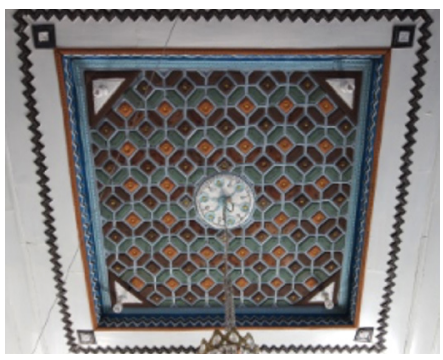

Kerpiçlik Mahallesi Camii

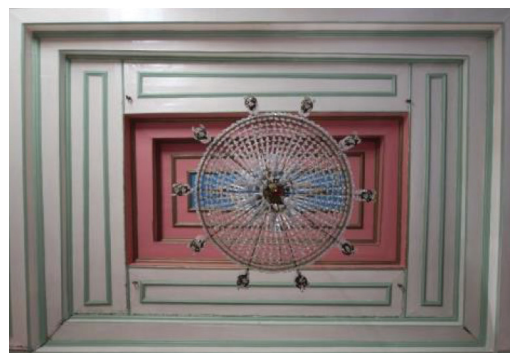

Beşiktaş Kaptan İbrahim Ağa Camii

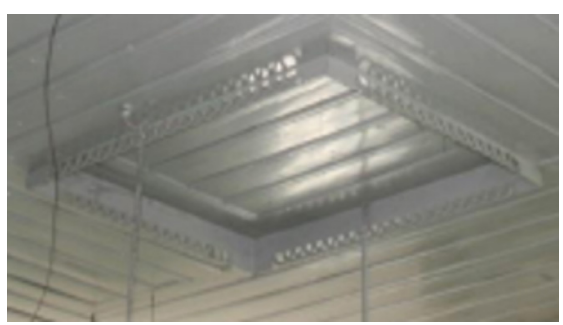

Merzifon Ortaova Köyü Camii

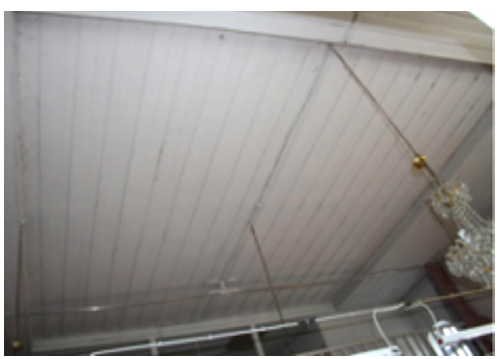

Merzifon Yeşilören Köyü Camii

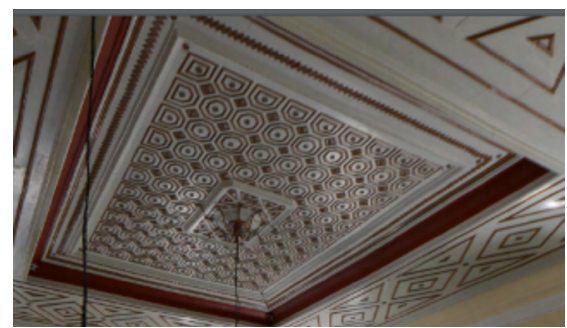

Muğla Ulu Camii 


\section{MÎZÂNÜ'L-HAK \\ ISLAMI ILIMLER DERGISI}

Tablo 4. Bitkisel motifli tavan göbek örnekleri

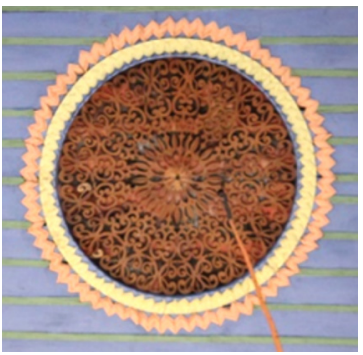

Küpeler Mahallesi Eski Camii

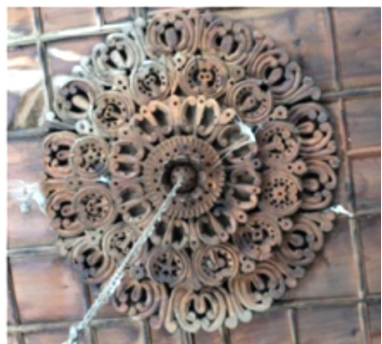

Sivrihisar Akdoğan Mescidi

Tablo 5. Geometrik motifli tavan göbek örnekleri

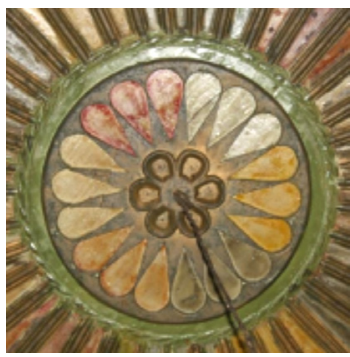

Amasya Göynücek Şıhlar Köyü Camii

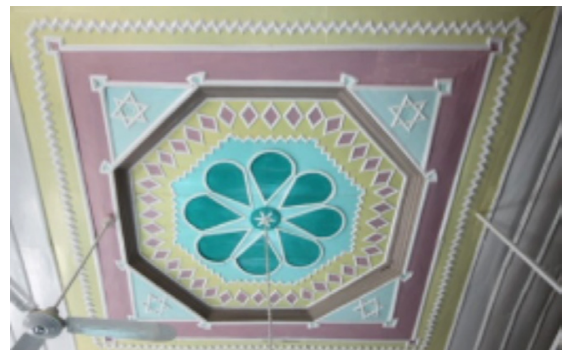

Sevinçler Mahallesi Camii

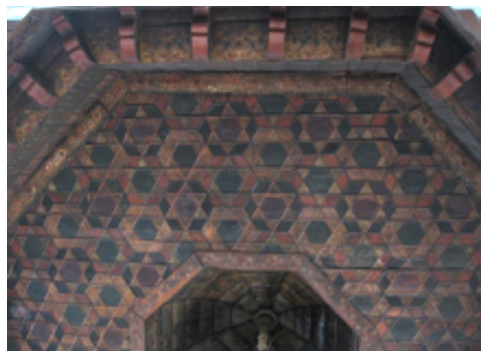

Merzifon ilçesi Büyük Hacı Hasan Camii

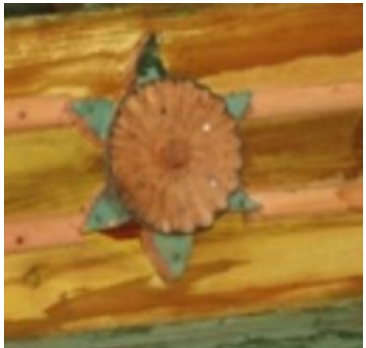

Amasya Büyük Kızılca Köyü İstasyon Camii 


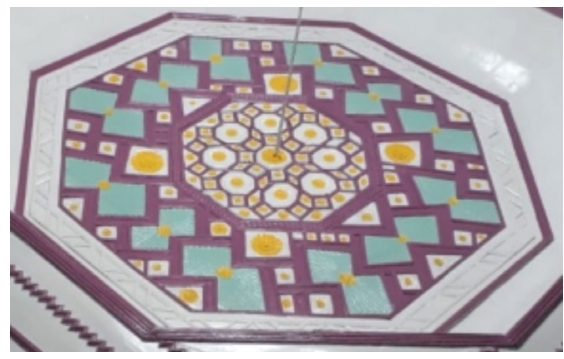

Kuloğlu Mahallesi Camii

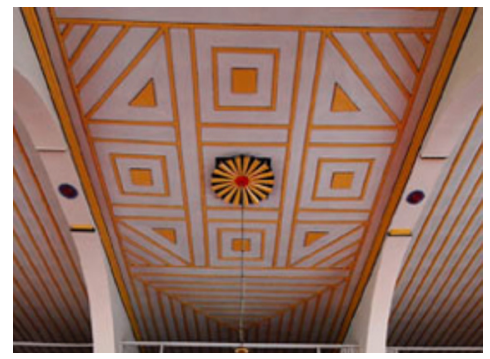

Konya Hacı Hasan Camii

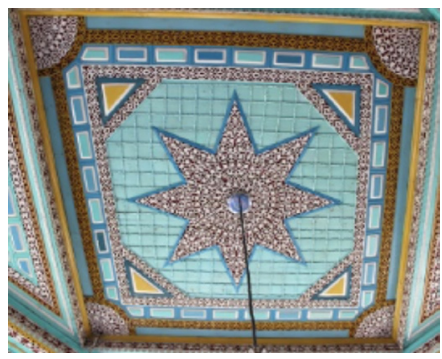

Söğütçük Mahallesi Camii

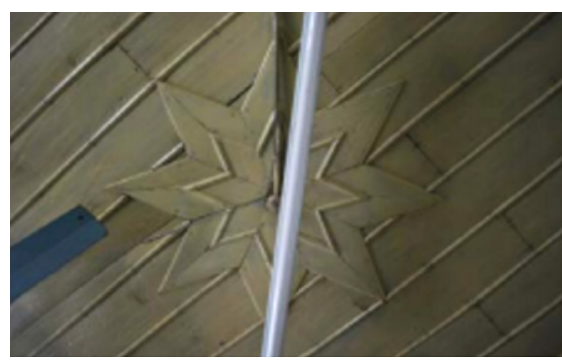

Elmalı Toklular Mescidi

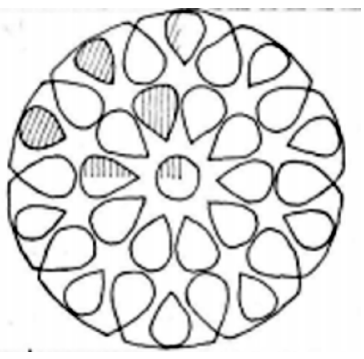

Aksaray Eski Ulu Camii

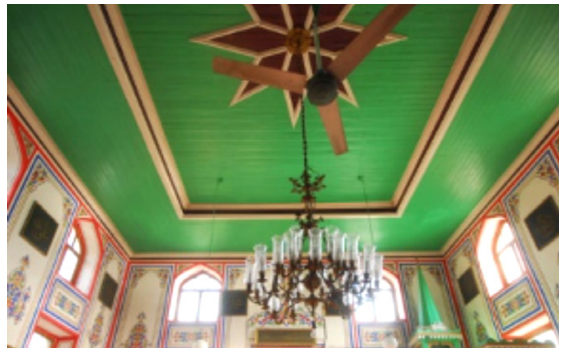

İstanbul Makbul İbrahim Paşa Camii

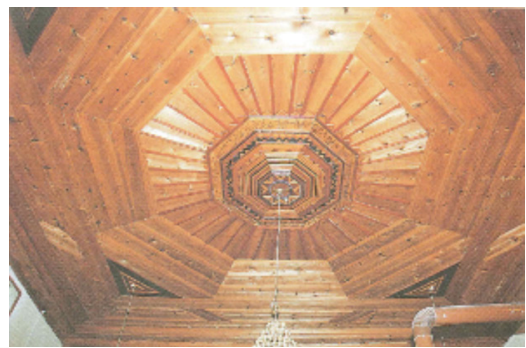

Kastamonu Çaycevher Köyü Camii

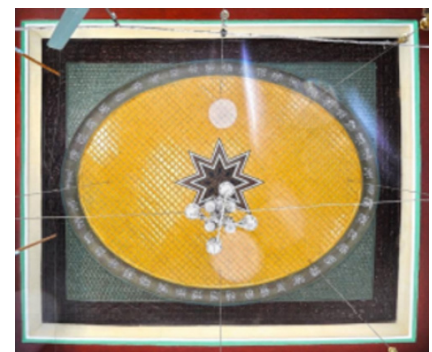

Burdur Günalan Köyü Lengüme Camii 


\section{Kaynaklar}

Acun, Hakkı. Manisa'da Türk Devri Yapıları. Ankara: TTK Yayınları, 1999.

Aktaşcı, Ö. "Çankııı/Kızılırmak Sakarca Köyü Camisi". Akademi Sosyal Bilimler Dergisi. 2019; 6(16): 1-18.

Aktemur, Ali Murat. "Türk Ahşap İşçiliği". Türkler, Cilt 6, Ankara: Yeni Türkiye Yayınları, 2002.

Arık, Rüçhan. Batılılaşma Dönemi Türk Mimarisi Örneklerinden Anadolu'da ÜçAhşap Cami. Ankara Üniversitesi Basımevi, 1973.

Arık, Rüçhan. Batılılaşma Dönemi Anadolu Tasvir Sanatı. Ankara: Kültür ve Turizm Bakanlığı Yayınları, 1988.

Arseven, Celal Esad. Türk Sanatı. Cem Yayınevi, 1984.

Ayvazoğlu, Beşir. Aşk Estetiği. İstanbul: Ötüken Yayınları, 2000.

Ayverdi, E. Hakkı ve İ. Aydın Yüksel. İlk 250 Senenin Osmanlı Mimarisi. Baha Matbaası: İstanbul, 1976.

Barışta, H. Örcün. Osmanlı Imparatorluğu Dönemi İstanbul Cami ve Türbelerinden Ağaç İşleri. Atatürk Kültür Merkezi Yayınları: Ankara, 2009.

Bozcu, Mustafa Murat. Burdur Ilinde Türk Mimarisi Selçukl., Beylikler ve Osmanlı Eserleri, Burdur Ticaret ve Sanayi Odası Yayınları: Burdur, (2013), 25, 62, 80.

Büyükkal, Aslı. Antalya Yöresi Mimarisinde Ahşap Malzemenin Kullanımı. Yüksek Lisans Tezi, Marmara Üniversitesi Sosyal Bilimler Enstitüsü, 2019.

Can, Yılmaz ve Recep Gün. Ana Hatlarılla Türk Islâm Sanatları ve Estetiği. İstanbul: Kayhan Yayınları, 2011.

Çal, Halit. Niğde Şehrindeki Ahşap Tavanlı Camiler ve Mescitler. Ankara: T.C Kültür Bakanlığı, 2000.

Çaycı, Ahmet. İslam Mimarisinde Anlam ve Sembol. Konya: Palet Yayınları, 2017.

Denktaş, Mustafa. "Pınarbaşı-Uzunyayla'daki Ahşap Direkli Camiler". Erciyes Üniversitesi Sosyal Bilimler Enstitüsü Dergisi, 16 (2004): 53 - 89.

Deniz, Bekir. "Aksaray'da (Niğde) Ahşap Sütunlu Iki Köy Cami." Arkeoloji-Sanat Dergisi, 4(4) 1988: 19-56.

Durukan, Aynur. "Safranbolu'daki Ahşap Tavanlı Camiler". I. Ulusal Tarih Içinde Safranbolu Sempozyumu (4-6 Mayıs 1999) Bildirileri Kitabı, 2003, 23-58.

Dündar, Mesut. "Çanakkale'de Geç Osmanlı Dönemi Camileri". Çanakkale Araştırmaları Türk Yıllığı, (2017): 15-23, 61-92.

Eryılmaz, Halil İbrahim. Türkiye'deki Il. Abdülhamid Camileri. İstanbul: Kitabevi Yayınları, 2019.

Eryılmaz, Halil İbrahim. Türk İslâm Sanatları Il. Ankara: Gazi Yayınları, 2020.

Grabar, Oleg. İslâm Sanatının Oluşumu. Çev. Nuran Yavuz, İstanbul: Kanat Yayınları, 2010.

Karaca, Burcu. Burdur ve Çevresinde Bulunan Camilerin Ahşap Üzerine Kalemişi Süslemeleri. Yüksek Lisans Tezi, Süleyman Demirel Üniversitesi, Isparta, 2017.

Karpuz, Haşim. "Erzurum ve Konya Evlerinde Ahşap Malzeme Kullanımı”. Ahşap Kültürü Anadolu'nun Ahşap Evleri. Ankara: Kültür Bakanlığı Yayınları, 2001.

Kılıç, Serkan. “Elmalı'daki Ahşap Tavanlı Cami ve Mescitler (Osmanlı Dönemi)". Mediterranean Journal of Humanities, 8/2 (2018): 407-425.

Koçyiğit, Fazilet. "Amasya'da Ahşap Tavanlı Iki Cami Örneği: Şıhlar ve Kızılkışlacık Köyü Camileri". Manas Sosyal Araştırmalar Dergisi, 8 (2), (2019): 1641-1658.

Korkmaz, Neslihan. "Amasya Camilerinde Ahşap Bindirme Tavan". Doktora Tezi, Anadolu Üniversitesi, 2016, 68-91. 
Kuban, Doğan. Kaybolan Kent Hayalleri Ahşap Saraylar. İstanbul:Yapı Endüstri Merkezi Yayınları, 2001. Kuban, Doğan. Osmanlı Mimarisi. İstanbul: Yem Yayınları, 2007.

Kuran, Aptullah. "Anadolu'da Ahşap Sütunlu Selçuklu Mimarisi." Malazgirt Armağanı, (1972): 179-186.

Kuyulu, İnci. "Geç Dönem Anadolu Tasvir Sanatından Yeni Bir Örnek: Soma Damgacı Camii”. Arkeoloji ve Sanat Tarihi Dergisi, 4 (1988): 67-78.

Kuyulu, İnci. “Bademli-Kılcızade Mehmet Ağa Cami (Ödemiş/İzmir)". Vakıflar Dergisi, 24 (1994): 147-158.

Mülayim, Selçuk. Anadolu Türk Mimarisinde Geometrik Süslemeler-Selçuklu Çağı. Ankara: Kültür Bakanlığı Yayınları, 1982.

Öney, Gönül. Anadolu Selçuklu Mimarisinde Süsleme ve El Sanatları. Ankara: Türkiye İş Bankası Yayınları, 1978.

Özay Çiğdem. "Geometrik Kompozisyonların Tokat Yapılarındaki Ahşap Tavan Göbeklerine Yansımasl; Mahmutpaşa Camii, Ulu Camii, Genç Mehmet Paşa Camii Örneği". Tokat Gaziosmanpaşa Üniversitesi Sosyal Bilimler Araştırmaları Dergisi, 15/1 (2020): 81-89.

Özen, Ramazan. "Inşaat Malzemesi Olarak Ahşap; Avantaj ve Dezavantajları". Ahşap Kültürü Anadolu’nun Ahşap Evleri, Ankara: Kültür Bakanlığı Yayınları, 2001.

Özgür Yıldız, Şenay ve Aliye Özsüner. "Bolu Göynük'te Türk Devri Mimarisi”. Düzce Üniversitesi Sosyal Bilimler Enstitüsü Dergisi, 10/2, (2020): 343-345.

Özkan, Haldun. Gümüşhane'de Ahşap Tavanlı Camiler." Sanat Dergisi, 18, (2011): 63 - 80.

Pala, İskender. "Mühr-i Süleyman". Diyanet İslâm Ansiklopedisi, 31, İstanbul: Diyanet Vakfı Yayınları, (2006): 524-526.

Parla, Canan ve Erol Altınsapan. "Sivrihisar Akdoğan Mescidi." Akademik Sosyal Araştırmalar Dergisi, 4/32, (2016): 1-11.

Ramazanoğlu, Gözde. Mimar Sinan'da Tezyinat Anlayışı. Ankara: Kültür Bakanlığı Yayınları, 1995.

Taşkan, Demet. "Ankara (Merkez) Cami ve Mescitlerindeki Ahşap Tavan Göbekleri". Gazi Üniversitesi Sosyal Bilimler Dergisi, Özel Sayı, (Aralık 2016): 71-101.

Uysal, Zekiye "18. Yüzyıldan Ahşap Direkli Iki Cami". Turkish Studies - International Periodical For The Languages, Literature and History of Turkish or Turki., 9/10 (Fall 2014): 1107-1123.

Ürer, Harun. "Izmir Kent Merkezinde Bulunan Cami ve Mescitlerden Örnekler". Tüba-Ked Türkiye Bilimler Akademisi Kültür Envanteri Dergisi, 16, (2017): 194-200.

Yücel, Erdem. "Selçuklu Ağaç İşçiliği." Sanat Dünyamız, 4, İstanbul: Yapı Kredi Yayınları, (1975): 3, 4, 5, 26.

Yücel, Erdem. "Ahşap". Diyanet İslâm Ansiklopedisi, 2, İstanbul: Diyanet Vakfı Yayınları, (1989): 182-183.

http://www.akmb.gov.tr/userfiles/files/\%C4\%BOLLER\%20VE\%20ULU\%20CAM\%C4\%BOLER\%C4\%B0/MU\%C4\%9ELA/MU\%C4\%9ELA\%20ULU\%20CAM\%C4\%B0\%C4\%B0/MU\%C4\%9ELA\%20ULU\%20CAM\%C4\%B0\%C4\%BO.pdf (Erişim tarihi 21.03.2021).

https://www.academia.edu/12508986/Do\%C4\%9Fu_Karadeniz_B\%C3\%B6lgesinde_Baz\%C4\%B1_ Ah\%C5\%9Fap_Camiler. (Erişim tarihi: 16.02.2021)

http://www.mustafacambaz.com/details.php?image_id=39170\&sessionid=fcd6bdf0a7c030d5667b39e4f673b727 (Erişim tarihi: 21.03.2021).

http://www.mustafacambaz.com/details.php?image_id=19875 (Erişim tarihi: 21.03.2021).

http://www.mustafacambaz.com/details.php?image_id=31369 (Erişim tarihi: 21.03.2021).

https://www.mustafacambaz.com/details.php?image_id=37538 (Erişim tarihi: 21.03.2021). 


\section{MÎZÂNÜ'L-HAK \\ ISLAMI ILIMLER DERGISI}

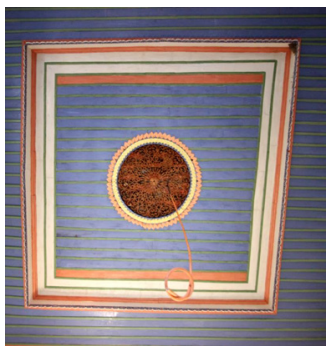

Fotoğraf 1: Küpeler Mahallesi Camii tavan göbeğinden genel görünüm

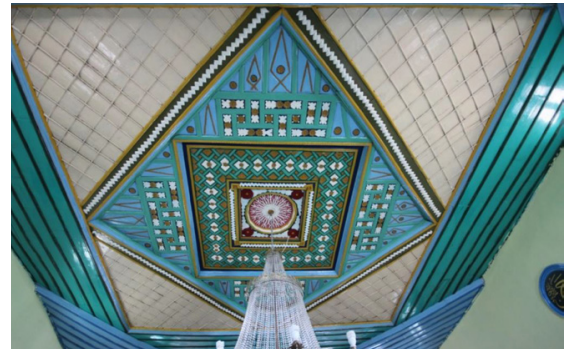

Fotoğraf 3: Üşümüş Mahallesi Camii tavanından genel görünüm

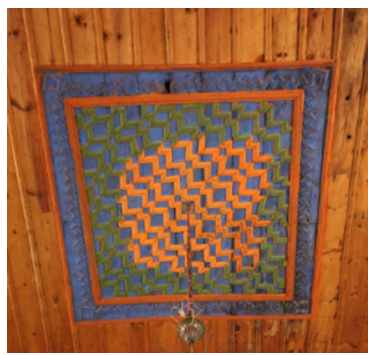

Fotoğraf 5: Köylüce Mahallesi Camii tavan göbeğinden genel görünüm

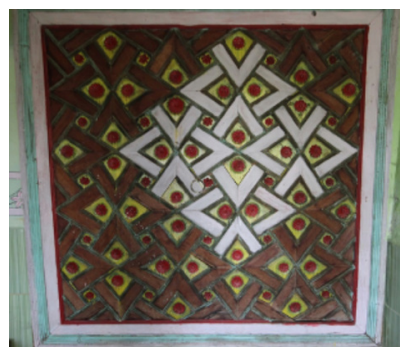

Fotoğraf 7: Ahatlar Mahallesi Camii eski tavan göbeğinden genel görünüm

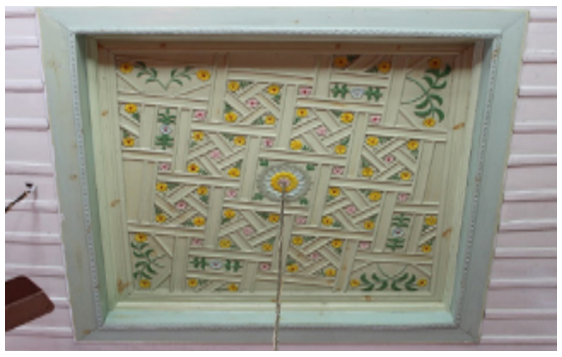

Fotoğraf 2: Ahmetler Mahallesi Camii tavan göbeğinden genel görünüm

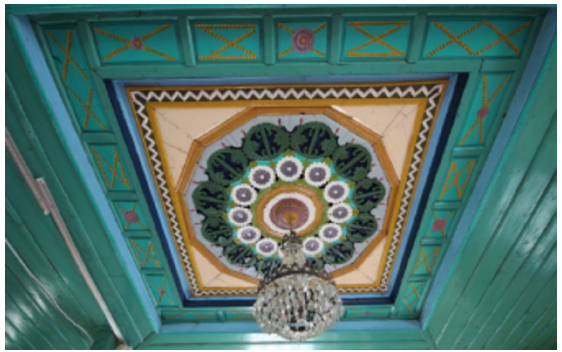

Fotoğraf 4: Üşümüş Mahallesi Camii kadınlar mahfili tavanından genel görünüm

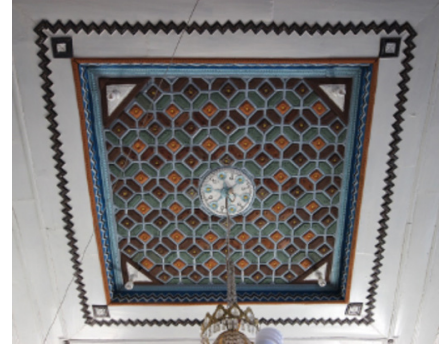

Fotoğraf 6: Kerpiçlik Mahallesi Camii tavan göbeğinden genel görünüm

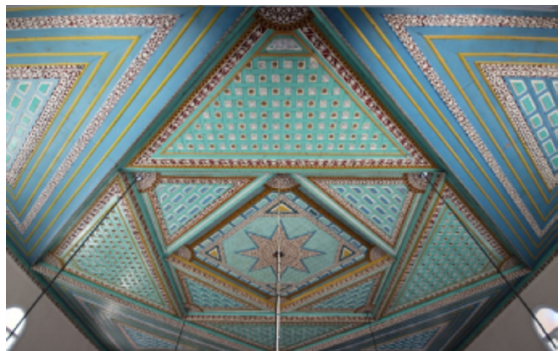

Fotoğraf 8: Söğütçük Mahallesi Camii tavanından genel görünüm 


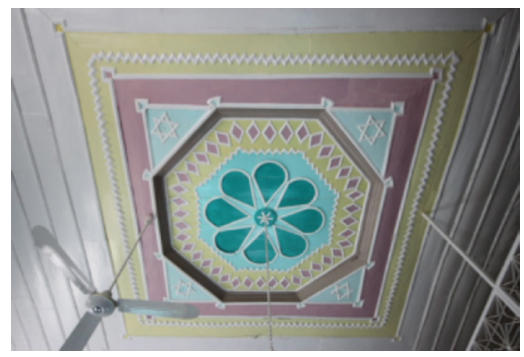

Fotoğraf 9: Sevinçler Mahallesi Eski Camii harim tavan göbeğinden genel görünüm

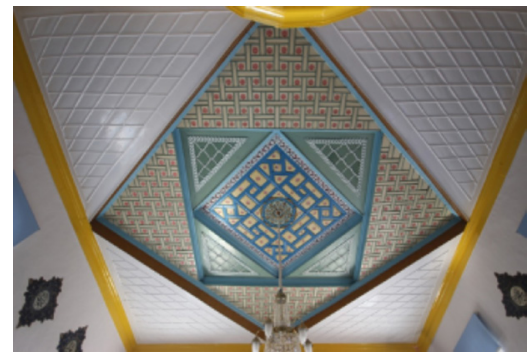

Fotoğraf 11: Çandır Mahallesi Camii harim tavanından genel görünüm

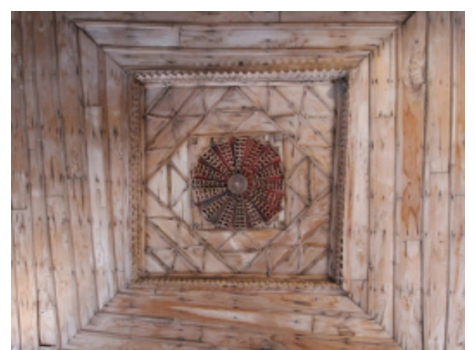

Fotoğraf 13: Boyacık Mahallesi Eski Camii harim tavan göbeğinden genel görünüm

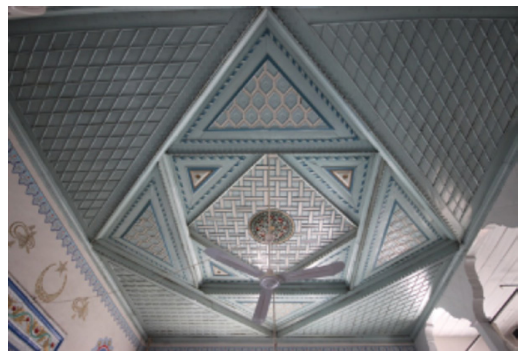

Fotoğraf 10: Esenyurt Mahallesi Camii harim tavanından genel görünüm

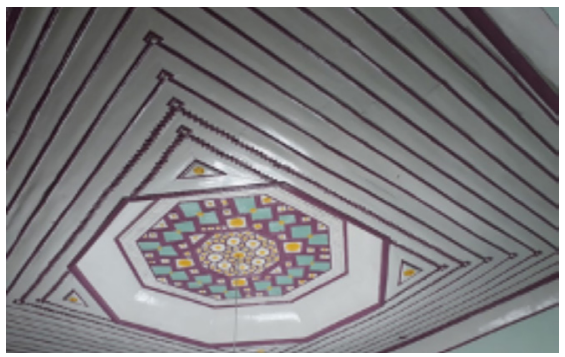

Fotoğraf 12: Merkez Kuloğlu Camii harim tavanından genel görünüm

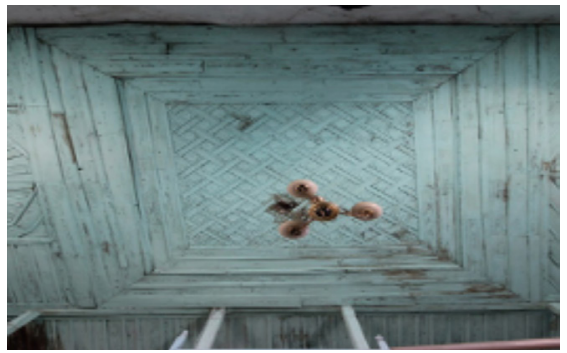

Fotoğraf 14: Kuzeyir Mahallesi Eski Camii harim tavan göbeğinden genel görünüm 
